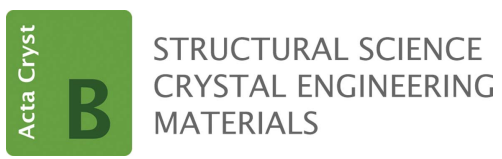

ISSN 2052-5206

Received 18 March 2020

Accepted 27 May 2020

Edited by J. Lipkowski, Polish Academy of Sciences, Poland

Keywords: polyoxometalates; minerals; structural complexity.

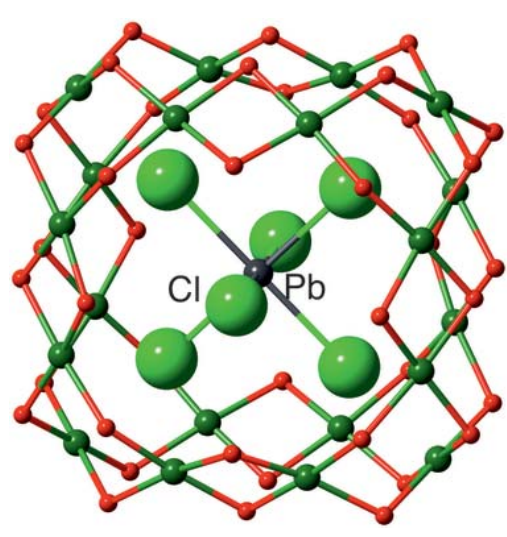

C 2020 International Union of Crystallography

\section{Polyoxometalate clusters in minerals: review and complexity analysis}

\author{
Sergey V. Krivovichev*
}

Department of Crystallography, Institute of Earth Sciences, St. Petersburg State University, University Emb. 7/9, St. Petersburg, 199034, Russian Federation, and Nanomaterials Research Centre, Kola Science Centre, Russian Academy of Sciences, Fersmana 14, Apatity, 184209, Russian Federation. *Correspondence e-mail: s.krivovichev@ksc.ru

Most research on polyoxometalates (POMs) has been devoted to synthetic compounds. However, recent mineralogical discoveries of POMs in mineral structures demonstrate their importance in geochemical systems. In total, 15 different types of POM nanoscale-size clusters in minerals are described herein, which occur in 42 different mineral species. The topological diversity of POM clusters in minerals is rather restricted compared to the multitude of moieties reported for synthetic compounds, but the lists of synthetic and natural POMs do not overlap completely. The metal-oxo clusters in the crystal structures of the vanarsite-group minerals $\left(\left[\mathrm{As}^{3+} \mathrm{V}^{4+}{ }_{2} \mathrm{~V}^{5+}{ }_{10} \mathrm{As}^{5+}{ }_{6} \mathrm{O}_{51}\right]^{7-}\right)$, bouazzerite and whitecapsite $\left(\left[M^{3+}{ }_{3} \mathrm{Fe}_{7}\left(\mathrm{AsO}_{4}\right)_{9} \mathrm{O}_{8-; n}(\mathrm{OH})_{n}\right]\right)$, putnisite $\left(\left[\mathrm{Cr}^{3+}{ }_{8}(\mathrm{OH})_{16}\left(\mathrm{CO}_{3}\right)_{8}\right]^{8-}\right)$, and ewingite $\left(\left[\left(\mathrm{UO}_{2}\right)_{24}\left(\mathrm{CO}_{3}\right)_{30} \mathrm{O}_{4}(\mathrm{OH})_{12}\left(\mathrm{H}_{2} \mathrm{O}\right)_{8}\right]^{32-}\right)$ contain metal-oxo clusters that have no close chemical or topological analogues in synthetic chemistry. The interesting feature of the POM cluster topologies in minerals is the presence of unusual coordination of metal atoms enforced by the topological restraints imposed upon the cluster geometry (the cubic coordination of $\mathrm{Fe}^{3+}$ and $\mathrm{Ti}^{4+}$ ions in arsmirandite and lehmannite, respectively, and the trigonal prismatic coordination of $\mathrm{Fe}^{3+}$ in bouazzerite and whitecapsite). Complexity analysis indicates that ewingite and morrisonite are the first and the second most structurally complex minerals known so far. The formation of nanoscale clusters can be viewed as one of the leading mechanisms of generating structural complexity in both minerals and synthetic inorganic crystalline compounds. The discovery of POM minerals is one of the specific landmarks of descriptive mineralogy and mineralogical crystallography of our time.

\section{Introduction}

Polyoxometalates (POMs) continue to be a subject of active and extensive research in inorganic chemistry, due to the amazing chemical and structural diversity of multinuclear polyoxoanions and their applications in crystal engineering and technology (Pope \& Müller, 1991, 1994, 2001; Miras et al., 2012, 2014). The field, which was traditionally associated with $d$-block metals in high oxidation states $\left(\mathrm{V}^{5+}, \mathrm{Nb}^{5+}, \mathrm{Ta}^{5+}, \mathrm{Mo}^{6+}\right.$ and $\mathrm{W}^{6+}$ ), has been extended in last two decades to POMs of other metals such as polyoxopalladates (Yang \& Kortz, 2018), polyoxocuprates (Kondinski \& Monakhov, 2017), uranium peroxide clusters (Nyman \& Burns, 2012; Qiu \& Burns, 2013), etc. Recently, a number of mineralogical discoveries of natural POMs have been reported in the literature (see references below), which have not only pure mineralogical interest as the extension of the mineral kingdom, but also point out to the importance of nanoscale clusters in geochemical environments. Along with the developments of the concepts of mineral evolution (Hazen et al., 2008), mineral ecology (Hazen et al., 2015), geo-inspired crystal engineering (Huskić et al., 2016, 2019; Huskić \& Friščić, 2018, 2019, 2020), the 
discoveries of natural POMs and nanotubules (Krivovichev et al., 2004; Rozhdestvenskaya et al., 2009, 2010, 2011, 2017) represent one of the most notable achievements of structural and descriptive mineralogy of the 21st century.

The aim of the present review is to summarize recent findings in the field of natural POMs and to analyze them from the viewpoint of the quantitative approach to structural complexity of crystals and minerals that we have developed over the last ten years (Krivovichev, 2012, 2013, 2014, 2016, 2017, 2018). The organization of mineral matter into nanoscale-size atomic objects is one of the most important complexity-generating mechanisms in mineral structures (Krivovichev, 2013; Olds et al., 2017). Together with the discoveries of silicate-based nanotubules in minerals, natural POMs open up a new area of research in mineralogy that becomes possible due to the methodological advances in crystallography such as the introduction of highly sensitive $\mathrm{X}$-ray detectors and the use of synchrotron radiation and electron diffraction techniques. Application of these technologies to the studies of crystalline mineral matter outlines the path for the future developments of structural mineralogy and nanogeochemistry.

In our review, we shall touch upon not only crystallographic aspects of natural POMs, but will also provide information on their genetic conditions in natural environments. As we shall demonstrate, the field of natural POMs overlaps with synthetic chemistry only partially, as there are several metal-oxygen clusters found in nature that have never been reported as artificial compounds. The systematic chemical description will be adopted, starting from 'traditional' POM chemistry of polyoxoniobates and polyoxovanadates and proceeding to the novel and sometimes old and forgotten discoveries of POMs in copper, iron, uranium and chromium minerals.

\section{Structural complexity analysis: methods}

Understanding the complexity of natural and synthetic systems, especially in quantitative terms that allow for analysis and comparison, is one of the important streamlines of modern science. For non-living nature this problem is less complex than for living systems, which have an unprecedented level of complexity with a human brain being the most complex natural system known so far (Kaku, 2014). Among non-living objects, crystals are understood as intuitively simple systems (Bennet, 1990), due to the periodic character of their structures (either three-periodic as for classical crystals or $n$ periodic $(n>3)$ for incommensurately modulated crystals and some quasicrystals).

The problem of quantifying structural complexity of crystals was considered at the very early stages of X-ray crystallography [see Krivovichev $(2013,2017)$ for historical remarks]. However, until recently no universal measure had been proposed that would be applicable to the broad range of crystals with periodic or quasi-periodic structure. As shown by Krivovichev $(2012$, 2014), the use of the Shannon information theory provides reasonable numerical estimates of structural complexity that at least theoretically are associated with the configurational entropies of crystals (Krivovichev, 2016).

In the framework of the proposed approach, the amounts of structural Shannon information per atom $\left({ }^{\text {str }} I_{\mathrm{G}}\right)$ and per unit cell $\left({ }^{\text {str }} I_{\mathrm{G}, \text { total }}\right)$ are calculated according to the following equations:

$$
\begin{gathered}
{ }^{\mathrm{str}} I_{\mathrm{G}}=-\sum_{i=1}^{k} p_{i} \log _{2} p_{i} \quad \text { (bits/atom) } \\
{ }^{\mathrm{str}} I_{\mathrm{G}, \text { total }}=-v I_{\mathrm{G}}=-v \sum_{i=1}^{k} p_{i} \log _{2} p_{i} \quad \text { (bits/cell), }
\end{gathered}
$$

where $k$ is the number of different crystallographic orbits in the structure and $p_{i}$ is the random choice probability for an atom from the $i$ th crystallographic orbit, that is:

$$
p_{i}=m_{i} / \nu,
$$

where $m_{i}$ is a multiplicity of a crystallographic orbit (i.e. the number of atoms of a specific Wyckoff site in the reduced unit cell) and $v$ is the total number of atoms in the reduced unit cell.

The Shannon information approach is applicable to any crystalline structure that can be characterized by a finite number] of atoms located in a finite amount of space with a defined equivalence relation among atomic sites (including trivial symmetry). The two measures of structural complexity, ${ }^{\text {str }} I_{\mathrm{G}}$ and ${ }^{\text {str }} I_{\mathrm{G}, \text { total }}$, reflect upon the two important properties of complexity, size and symmetry of the system. While the parameter ${ }^{\text {str }} I_{\mathrm{G}}$ is sensitive to symmetry, the parameter ${ }^{\text {str }} I_{\mathrm{G}, \text { total }}$ is sensitive to both symmetry and the number of translationally independent sites, i.e. the size of the system.

Krivovichev $(2013$, 2014) classified all inorganic crystal structures according to their ${ }^{\text {str }} I_{\mathrm{G} \text {,total }}$ value into five groups (bits/cell): very simple (0-50), simple (50-100), intermediately complex (100-500), complex (500-1000) and very complex (> 1000 bits/cell).

\section{Polyoxometalate clusters in minerals: diversity}

Tables 1, 2 and 3 provide information on minerals containing natural POM clusters, including mineral name, chemical formula, cluster nuclearity (the number of metal atoms in a cluster), and both parameters of structural complexity, ${ }^{\text {str }} I_{\mathrm{G}}$ and ${ }^{\mathrm{str}} I_{\mathrm{G}, \text { total }}$. The calculation of the information-based complexity measures was performed using TOPOS (Blatov et al., 2014) on the basis of atomic coordinates reported in the original publications. For those minerals, where positions of $\mathrm{H}$ atoms have not been determined, the procedure of $\mathrm{H}$ correction was applied (Pankova et al., 2018) by the introduction of surrogate $\mathrm{H}$ sites with respective multiplicities. Below we provide a systematic discussion of POMs in minerals, along with the analysis of the complexity of their structures and the peculiarities of their origin in nature.

\subsection{Polyoxoniobates}

The polyoxoniobate anion, $\left[\mathrm{Nb}_{6} \mathrm{O}_{19}\right]^{8-}$, is the simplest natural polyoxometalate cluster, consisting of six $\left(\mathrm{NbO}_{6}\right)$ octahedra sharing one central O atom [Fig. 1(a)]. It is well 
Table 1

Minerals containing polyoxoniobate and polyoxotungstate clusters and their structural complexity parameters.

$N=$ cluster nuclearity; polyoxometalate clusters shown in square brackets.

\begin{tabular}{|c|c|c|c|c|c|}
\hline Mineral name & Chemical formula & $N$ & Ref. & $\begin{array}{l}{ }^{\mathrm{str}} I_{\mathrm{G}} \\
\text { (bits/atom) }\end{array}$ & $\begin{array}{l}{ }^{\text {str }} I_{\mathrm{G}, \text { total }} \\
\text { (bits/cell) }\end{array}$ \\
\hline Peterandresenite & $\mathrm{Mn}_{4}\left[\mathrm{Nb}_{6} \mathrm{O}_{19}\right] \cdot 14 \mathrm{H}_{2} \mathrm{O}$ & 6 & 1 & 4.488 & 318.632 \\
\hline Hansesmarkite & $\mathrm{Ca}_{2} \mathrm{Mn}_{2}\left[\mathrm{Nb}_{6} \mathrm{O}_{19}\right] \cdot 20 \mathrm{H}_{2} \mathrm{O}$ & 6 & 2 & 5.487 & 488.340 \\
\hline Melcherite & $\mathrm{Ba}_{2} \mathrm{Na}_{2} \mathrm{Mg}\left[\mathrm{Nb}_{6} \mathrm{O}_{19}\right] \cdot 6 \mathrm{H}_{2} \mathrm{O}$ & 6 & 3 & 3.240 & 311.020 \\
\hline Ophirite & $\mathrm{Ca}_{2} \mathrm{Mg}_{4}\left[\mathrm{Zn}_{2} \mathrm{Mn}^{3+}{ }_{2}\left(\mathrm{H}_{2} \mathrm{O}\right)_{2}\left(\mathrm{Fe}^{3+} \mathrm{W}_{9} \mathrm{O}_{34}\right)_{2}\right] \cdot 46 \mathrm{H}_{2} \mathrm{O}$ & 24 & 4 & 6.919 & 1674.365 \\
\hline
\end{tabular}

References: (1) Friis et al. (2014), (2) Friis et al. (2017), (3) Andrade et al. (2018), (4) Kampf et al. (2014c).

Table 2

Minerals containing polyoxovanadate clusters and their structural complexity parameters.

$N$ = cluster nuclearity; polyoxometalate clusters shown in square brackets.

\begin{tabular}{|c|c|c|c|c|c|}
\hline Mineral name & Chemical formula & $N$ & Ref. & $\begin{array}{l}{ }^{\mathrm{str}} I_{\mathrm{G}} \\
\text { (bits/atom) }\end{array}$ & $\begin{array}{l}{ }^{\text {str }} I_{\mathrm{G}, \text { total }} \\
\text { (bits/cell) }\end{array}$ \\
\hline Pascoite & $\mathrm{Ca}_{3}\left[\mathrm{~V}_{10} \mathrm{O}_{28}\right] \cdot 17 \mathrm{H}_{2} \mathrm{O}$ & 10 & 1 & 4.768 & 424.340 \\
\hline Hydropascoite & $\mathrm{Ca}_{3}\left[\mathrm{~V}_{10} \mathrm{O}_{28}\right] \cdot 24 \mathrm{H}_{2} \mathrm{O}$ & 10 & 2 & 6.820 & 1541.360 \\
\hline Magnesiopascoite & $\mathrm{Ca}_{2} \mathrm{Mg}\left[\mathrm{V}_{10} \mathrm{O}_{28}\right] \cdot 16 \mathrm{H}_{2} \mathrm{O}$ & 10 & 3 & 4.768 & 424.340 \\
\hline Huemulite & $\mathrm{Na}_{4} \mathrm{Mg}\left[\mathrm{V}_{10} \mathrm{O}_{28}\right] \cdot 24 \mathrm{H}_{2} \mathrm{O}$ & 10 & 4 & 5.821 & 646.180 \\
\hline Okieite & $\mathrm{Mg}_{3}\left[\mathrm{~V}_{10} \mathrm{O}_{28}\right] \cdot 28 \mathrm{H}_{2} \mathrm{O}$ & 10 & 5 & 6.966 & 1741.446 \\
\hline Lasalite & $\mathrm{Na}_{2} \mathrm{Mg}_{2}\left[\mathrm{~V}_{10} \mathrm{O}_{28}\right] \cdot 20 \mathrm{H}_{2} \mathrm{O}$ & 10 & 6 & 5.672 & 1157.175 \\
\hline Ammoniolasalite & {$\left[\left(\mathrm{NH}_{4}\right)_{2} \mathrm{Mg}_{2}\left(\mathrm{H}_{2} \mathrm{O}\right)_{20}\right] \cdot\left[\mathrm{V}_{10} \mathrm{O}_{28}\right]$} & 10 & 7 & 5.781 & 1271.899 \\
\hline Bluestreakite & $\mathrm{K}_{4} \mathrm{Mg}_{2}\left[\mathrm{~V}^{4+}{ }_{2} \mathrm{~V}^{5+}{ }_{8} \mathrm{O}_{28}\right] \cdot 14 \mathrm{H}_{2} \mathrm{O}$ & 10 & 8 & 5.426 & 933.318 \\
\hline Kokinosite & $\mathrm{Na}_{2} \mathrm{Ca}_{2}\left[\mathrm{~V}_{10} \mathrm{O}_{28}\right] \cdot 24 \mathrm{H}_{2} \mathrm{O}$ & 10 & 9 & 5.807 & 650.424 \\
\hline Burroite & $\mathrm{Ca}_{2}\left(\mathrm{NH}_{4}\right)_{2}\left[\mathrm{~V}_{10} \mathrm{O}_{28}\right] \cdot 15 \mathrm{H}_{2} \mathrm{O}$ & 10 & 10 & 5.492 & 494.267 \\
\hline Gunterite & $\mathrm{Na}_{4}\left(\mathrm{H}_{2} \mathrm{O}\right)_{16}\left[\mathrm{H}_{2} \mathrm{~V}_{10} \mathrm{O}_{28}\right] \cdot 6 \mathrm{H}_{2} \mathrm{O}$ & 10 & 11 & 5.125 & 553.528 \\
\hline Hughesite & $\mathrm{Na}_{3} \mathrm{AlV}_{10} \mathrm{O}_{28} \cdot 22 \mathrm{H}_{2} \mathrm{O}$ & 10 & 12 & 5.773 & 623.528 \\
\hline Nashite & $\mathrm{Na}_{3} \mathrm{Ca}_{2}\left[\left(\mathrm{~V}^{4+} \mathrm{V}^{5+}{ }_{9}\right) \mathrm{O}_{28}\right] \cdot 24 \mathrm{H}_{2} \mathrm{O}$ & 10 & 13 & 5.858 & 1359.052 \\
\hline Postite & $\mathrm{Mg}\left(\mathrm{H}_{2} \mathrm{O}\right)_{6} \mathrm{Al}_{2}(\mathrm{OH})_{2}\left(\mathrm{H}_{2} \mathrm{O}\right)_{8}\left[\mathrm{~V}_{10} \mathrm{O}_{28}\right] \cdot 13 \mathrm{H}_{2} \mathrm{O}$ & 10 & 14 & 5.993 & 3020.549 \\
\hline Rakovanite & $\mathrm{Na}_{3}\left\{\mathrm{H}_{3}\left[\mathrm{~V}_{10} \mathrm{O}_{28}\right]\right\} \cdot 15 \mathrm{H}_{2} \mathrm{O}$ & 10 & 15 & 6.426 & 2210.635 \\
\hline Schindlerite & $\left\{\left(\mathrm{NH}_{4}\right)_{4} \mathrm{Na}_{2}\left(\mathrm{H}_{2} \mathrm{O}\right)_{10}\right\}\left[\mathrm{V}_{10} \mathrm{O}_{28}\right]$ & 10 & 16 & 5.426 & 466.659 \\
\hline Wernerbaurite & $\left\{\left(\mathrm{NH}_{4}\right)_{2}\left[\mathrm{Ca}_{2}\left(\mathrm{H}_{2} \mathrm{O}\right)_{14}\right]\left(\mathrm{H}_{2} \mathrm{O}\right)_{2}\right\}\left[\mathrm{V}_{10} \mathrm{O}_{28}\right]$ & 10 & 16 & 5.589 & 536.156 \\
\hline Caseyite & $\begin{array}{l}{\left[\left(\mathrm{V}^{5+} \mathrm{O}_{2}\right) \mathrm{Al}_{10-x}(\mathrm{OH})_{20-2 x}\left(\mathrm{H}_{2} \mathrm{O}\right)_{18-2 x}\right]_{2}\left[\mathrm{H}_{2} \mathrm{~V}^{4+} \mathrm{V}^{5+}{ }_{9} \mathrm{O}_{28}\right]-} \\
{\left[\mathrm{V}^{5+}{ }_{10} \mathrm{O}_{28}\right]_{2}(\mathrm{Na}, \mathrm{K}, \mathrm{Ca})_{2-y}\left(\mathrm{SO}_{4}\right)_{2-z} \cdot(60+8 x+y+4 z) \mathrm{H}_{2} \mathrm{O}} \\
\quad(x=0-2.5 ; y=0-2 ; z=0-2)\end{array}$ & 10 & 17 & 7.170 & 4129.877 \\
\hline Kegginite & $\mathrm{Pb}_{3} \mathrm{Ca}_{3}\left[\mathrm{AsV}_{12} \mathrm{O}_{40}(\mathrm{VO})\right] \cdot 20 \mathrm{H}_{2} \mathrm{O}$ & 13 & 18 & 5.477 & 1402.099 \\
\hline Sherwoodite & $\mathrm{Ca}_{4.5}\left[\mathrm{AlV}^{4+}{ }_{2} \mathrm{~V}^{5+}{ }_{12} \mathrm{O}_{40}\right] \cdot 28 \mathrm{H}_{2} \mathrm{O}$ & 15 & 19 & 4.149 & 945.899 \\
\hline Bicapite & {$\left[\mathrm{KNa}_{2} \mathrm{Mg}_{2}\left(\mathrm{H}_{2} \mathrm{O}\right)_{25}\right]\left[\mathrm{H}_{2} \mathrm{PV}^{5+}{ }_{12} \mathrm{O}_{40}\left(\mathrm{~V}^{5+} \mathrm{O}\right)_{2}\right]$} & 15 & 20 & 4.446 & 631.264 \\
\hline Morrisonite & $\mathrm{Ca}_{11}\left[\mathrm{As}^{3+} \mathrm{V}^{4+}{ }_{2} \mathrm{~V}^{5+}{ }_{10} \mathrm{As}^{5+}{ }_{6} \mathrm{O}_{51}\right]_{2} \cdot 78 \mathrm{H}_{2} \mathrm{O}$ & 19 & 21 & 8.622 & 13558.354 \\
\hline Vanarsite & $\left.\mathrm{NaCa}_{12}\left[\mathrm{As}^{3+} \mathrm{V}^{5+}{ }_{8.5} \mathrm{~V}^{4+}{ }_{3.5} \mathrm{As}^{5+}{ }_{6} \mathrm{O}_{51}\right]\right]_{2} \cdot 78 \mathrm{H}_{2} \mathrm{O}$ & 19 & 21 & 7.621 & 5990.051 \\
\hline Packratite & $\mathrm{Ca}_{11}\left[\mathrm{As}^{3+} \mathrm{V}^{5+}{ }_{10} \mathrm{~V}^{4+}{ }_{2} \mathrm{As}^{5+}{ }_{6} \mathrm{O}_{51}\right]_{2} \cdot 83 \mathrm{H}_{2} \mathrm{O}$ & 19 & 21 & 7.972 & 4001.715 \\
\hline Gatewayite & $\mathrm{Ca}_{6}\left[\mathrm{As}^{3+} \mathrm{V}^{4+}{ }_{3} \mathrm{~V}^{5+}{ }_{9} \mathrm{As}^{5+}{ }_{6} \mathrm{O}_{51}\right] \cdot 31 \mathrm{H}_{2} \mathrm{O}$ & 19 & 21 & 7.418 & 2536.906 \\
\hline Lumsdenite & $\mathrm{NaCa}_{3} \mathrm{Mg}_{2}\left[\mathrm{As}^{3+} \mathrm{V}_{2+}^{4+} \mathrm{V}^{5+}{ }_{10} \mathrm{As}^{5+}{ }_{6} \mathrm{O}_{51}\right] \cdot 45 \mathrm{H}_{2} \mathrm{O}$ & 19 & 22 & 6.919 & 1674.365 \\
\hline
\end{tabular}

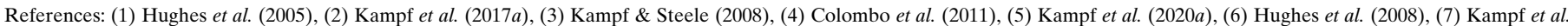

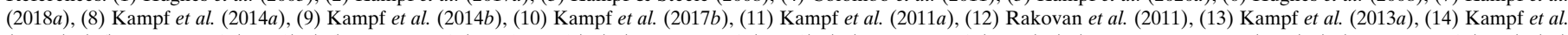

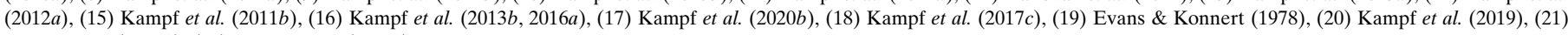
Kampf et al. (2016b), (22) Kampf et al. (2020c).

known in chemistry as a Lindqvist anion, first reported by Lindqvist (1953). The skeletal representation of the anion is rather simple as well and corresponds to a regular or slightly distorted octahedron [Fig. 1(a)]. The first occurrence of Lindqvist ions in minerals was reported by Friis et al. (2014, 2017), who found this cluster in the crystal structures of two closely related and paragenetically associated minerals, peterandresenite and hansesmarkite, discovered in alkaline rocks in Tvedalen, Larvik, Vestfold, Norway. Both minerals were found as secondary (last-to-form) minerals grown on the surface of zeolites, e.g. natrolite, indicating their formation at rather a low temperature (less than $100^{\circ} \mathrm{C}$ ). The alkaline nature of the rocks, where the two minerals have been found, is in agreement with the synthesis conditions of hexaniobates, which crystallize under $\mathrm{pH}>8$ (Etxebarria et al., 1994). Friis \& Casey (2018) pointed out that the discovery of peterandresenite and hansesmarkite represents a challenge for traditional geochemistry that does not take into account complex reaction paths involving aqueous polyoxometalate species. In particular, niobium in the form of Lindqvist ions is much more mobile than it was previously thought (Friis \& Casey, 2018). Andrade et al. (2018) reported the discovery of another natural polyoxoniobate, melcherite, which was found as a late carbonatite vug mineral in the Jacupiranga mine, Cajati County, São Paulo, Brazil. Melcherite had also formed under low-temperature conditions at the last stages of 
Table 3

Miscellanous minerals containing polyoxometalate clusters and their structural complexity parameters.

$N$ = cluster nuclearity; polyoxometalate clusters shown in square brackets.

\begin{tabular}{|c|c|c|c|c|c|}
\hline Mineral name & Chemical formula & $N$ & Ref. & $\begin{array}{l}{ }^{\text {str }} I_{\mathrm{G}} \\
\text { (bits/atom) }\end{array}$ & $\begin{array}{l}{ }^{\text {str }} I_{\mathrm{G}, \text { total }} \\
\text { (bits/cell) }\end{array}$ \\
\hline Natrophosphate & $\mathrm{Na}\left[\mathrm{Na}_{6} \mathrm{~F}\left(\mathrm{H}_{2} \mathrm{O}\right)_{18}\right]\left(\mathrm{PO}_{4}\right)_{2}\left(\mathrm{H}_{2} \mathrm{O}\right)$ & 6 & 1,2 & 3.713 & 2109.177 \\
\hline Bouazzerite & $(\mathrm{Mg}, \mathrm{Co})_{11}\left[\mathrm{Bi}_{3} \mathrm{Fe}_{7}\left(\mathrm{AsO}_{4}\right)_{9} \mathrm{O}_{6}(\mathrm{OH})_{2}\right]_{2} \cdot 86 \mathrm{H}_{2} \mathrm{O}$ & 16 & 3 & 7.636 & 6062.598 \\
\hline Arsmirandite & $\mathrm{Na}_{18}\left[\mathrm{Cu}_{12}{ }^{2+} \mathrm{Fe}^{3+} \mathrm{O}_{8}\left(\mathrm{AsO}_{4}\right)_{8}\right] \mathrm{Cl}_{5}$ & 21 & 5 & 4.678 & 392.955 \\
\hline Lehmannite & $\mathrm{Na}_{18}\left[\mathrm{Cu}_{12}{ }^{2+} \mathrm{Ti}^{4+} \mathrm{O}_{8}\left(\mathrm{AsO}_{4}\right)_{8}\right] \mathrm{FCl}_{5}$ & 21 & 5 & 4.765 & 414.536 \\
\hline Tschörtnerite & $\mathrm{Ca}_{16}(\mathrm{Ca}, \mathrm{Sr}, \mathrm{K}, \mathrm{Ba})_{12}\left[\mathrm{Cu}_{12}(\mathrm{OH})_{24}\right]\left[\mathrm{Al}_{3} \mathrm{Si}_{3} \mathrm{O}_{12}\right]_{16}(\mathrm{OH})_{8} \cdot n \mathrm{H}_{2} \mathrm{O}$ & 12 & 6 & 5.081 & 5421.227 \\
\hline Pseudoboleite & $\mathrm{Pb}_{31}\left[\mathrm{Cu}_{24}(\mathrm{OH})_{48}\right] \mathrm{Cl}_{62}$ & 24 & 10 & 4.640 & 1011.464 \\
\hline Putnisite & $\mathrm{SrCa}_{4}\left[\mathrm{Cr}_{8}^{3+}(\mathrm{OH})_{16}\left(\mathrm{CO}_{3}\right)_{8}\right]\left(\mathrm{SO}_{4}\right) \cdot 25 \mathrm{H}_{2} \mathrm{O}$ & 16 & 11 & 6.059 & 2932.730 \\
\hline Ramazzoite & {$\left[\mathrm{Mg}_{8} \mathrm{Cu}_{12}\left(\mathrm{PO}_{4}\right)\left(\mathrm{CO}_{3}\right)_{4}(\mathrm{OH})_{24}\left(\mathrm{H}_{2} \mathrm{O}\right)_{20}\right]\left[\left(\mathrm{H}_{0.33} \mathrm{SO}_{4}\right)_{3}\left(\mathrm{H}_{2} \mathrm{O}\right)_{36}\right]$} & 25 & 12 & 4.620 & 1848.162 \\
\hline Ewingite & $\mathrm{Mg}_{8} \mathrm{Ca}_{8}\left[\left(\mathrm{UO}_{2}\right)_{24}\left(\mathrm{CO}_{3}\right)_{30} \mathrm{O}_{4}(\mathrm{OH})_{12}\left(\mathrm{H}_{2} \mathrm{O}\right)_{8}\right]\left(\mathrm{H}_{2} \mathrm{O}\right)_{130}$ & 54 & 13 & 7.603 & 23477.507 \\
\hline
\end{tabular}

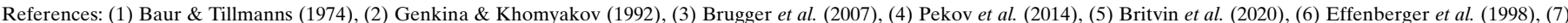

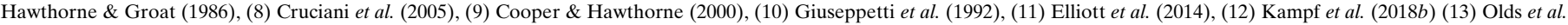
(2017)

hydrothermal activity. The low nuclearity of the hexaniobate ion results in relatively low structural complexities of peterandresenite, hansesmarkite and melcherite (300-500 bits/cell; Table 1); all three species belong to the group of minerals of intermediate complexity.

The occurrence of Lindqvist-type clusters in minerals is not restricted to niobates. The crystal structure of natrophosphate, a late low-temperature hydrothermal mineral from alkaline rocks (Kapustin et al., 1972) and a major salt in alkaline nuclear waste (Reynolds et al., 2013; Herting \& Reynolds, $2016)$, contains the superoctahedral $\left[\mathrm{Na}_{6} \mathrm{~F}\left(\mathrm{H}_{2} \mathrm{O}\right)_{18}\right]^{5+}$ polycation built from six $\left[\mathrm{NaF}\left(\mathrm{H}_{2} \mathrm{O}\right)_{5}\right]$ octahedra sharing a central $\mathrm{F}$ atom. In contrast to hexaniobates, natrophosphate has a very complex structure with 2109.177 bits of Shannon information per unit cell.
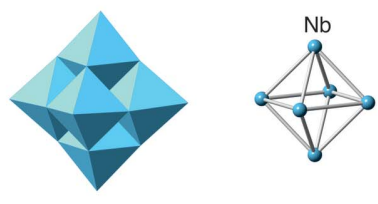

(a)
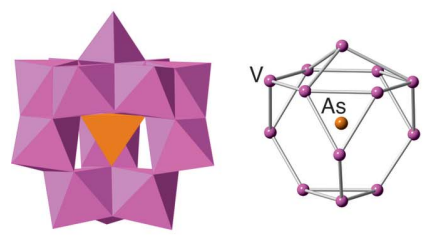

(c)
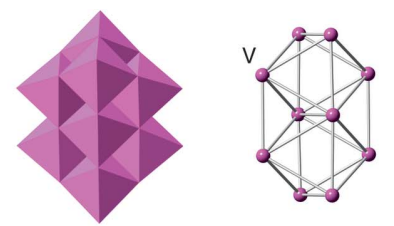

(b)
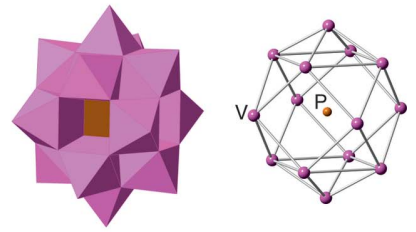

$(d)$

Figure 1

Polyoxometalate clusters in minerals shown in polyhedral (left) and skeletal (right) representations: the $\left[\mathrm{Nb}_{6} \mathrm{O}_{19}\right]^{8-}$ cluster in melcherite $(a)$, the $\left[\mathrm{V}_{10} \mathrm{O}_{28}\right]^{6-}$ cluster in pascoite $(b)$, the $\left[\mathrm{AsV}_{12} \mathrm{O}_{40}(\mathrm{VO})\right]^{12-}$ cluster in kegginite $(c)$, and the $\left[\mathrm{H}_{2} \mathrm{PV}^{5+}{ }_{12} \mathrm{O}_{40}\left(\mathrm{~V}^{5+} \mathrm{O}\right)_{2}\right]^{7-}$ cluster in bicapite $(d)$.

\subsection{Polyoxovanadates}

Polyoxovanadates constitute the most diverse group of minerals containing POM clusters, both in terms of the number of minerals (26 species reported so far) and the topological diversity (five different POM topologies) (Table 2). The most common cluster is a decavanadate anion, $\left[\mathrm{V}_{10} \mathrm{O}_{28}\right]^{n-}$, consisting of ten $\left(\mathrm{VO}_{6}\right)$ octahedra and occurring in 17 different mineral species [Fig. 1(b)]. The anion can be considered as two Lindqvist ions sharing a pair of octahedra. When all vanadium is fully oxidized as $\mathrm{V}^{5+}$, the anion has the formula $\left[\mathrm{V}_{10} \mathrm{O}_{28}\right]^{6-}$, but anions with partially oxidized $\mathrm{V}$ (with mixed $\mathrm{V}^{4+}-\mathrm{V}^{5+}$ compositions) formed under reducing conditions are also known (Cooper et al., 2019a). Under acidic conditions, protonated decavanadate ions, $\left[\mathrm{H}_{x} \mathrm{~V}_{10} \mathrm{O}_{28}\right]^{(6-x)-}$, may form as well (Cooper et al., 2019b).

The first mineral containing decavanadate POM clusters, pascoite, was described more than 100 years ago by Hillebrand et al. (1914) from the Minasragra mine, Pasco Department, Peru, where the mineral crystallized on the walls of an exploratory tunnel after its excavation. The crystal structure of pascoite was first reported by Swallow et al. (1966) and refined by Hughes et al. (2005). Later pascoite and other minerals of the pascoite group have been found in the uranium-vanadium mineral deposits of the Uravan Mineral Belt, Colorado and Utah, USA (Kampf et al., 2020b), uranium orebodies of the Malargüe area, Mendoza Province, Argentina (Gordillo et al., 1966), and other localities. In all cases, the decavanadate minerals typically form in mine tunnels under ambient temperatures, crystallizing from near-surface aqueous solutions. In a certain sense, the formation of these minerals in nature involved indirect anthropogenic actions induced by mining activities.

In terms of structural complexity, most of the pascoitegroup minerals are either complex (500-1000 bits/cell) or very complex (> 1000 bits/cell). The two most complex minerals of the group are caseyite (4129.877 bits/cell; Kampf et al., 2020b) and postite (3020.549 bits/cell; Kampf et al., 2012). In both 
cases, the high structural complexity is the result of the presence of additional structural constituents that are not parts of the decavanadate ions. The crystal structure of caseyite is absolutely unique in that it contains two types of decavanadate anions, $\left[\mathrm{H}_{2} \mathrm{~V}^{4+} \mathrm{V}^{5+}{ }_{9} \mathrm{O}_{28}\right]^{5-}$ and $\left[\mathrm{V}^{5+}{ }_{10} \mathrm{O}_{28}\right]^{6-}$, and the flat $\left[\left(\mathrm{V}^{5+} \mathrm{O}_{2}\right) \mathrm{Al}_{10-x}(\mathrm{OH})_{20-2 x}\left(\mathrm{H}_{2} \mathrm{O}\right)_{18-2 x}\right]^{11+}$ polycations (see below). The complexity of the crystal structure of postite is due to the presence of two different kinds of interstitial units, the isolated $\left[\mathrm{Mg}\left(\mathrm{H}_{2} \mathrm{O}\right)_{6}\right]^{2+}$ octahedra and the $\left[\mathrm{Al}_{2}(\mathrm{OH})_{2}\left(\mathrm{H}_{2} \mathrm{O}\right)_{8}\right]^{4+}$ dimers of two edge-sharing Al-centred octahedra.

The Keggin structure first elucidated by J. F. Keggin in 1930s (Keggin, 1934) is one of the central and most common topologies in the POM chemistry (Kondinski \& Parac-Vogt, 2018). The Keggin ion has the formula $\left[X M_{12} \mathrm{O}_{40}\right]$ and consists of a central $X_{\mathrm{O}_{4}}$ tetrahedron surrounded by the $\left[M_{3} \mathrm{O}_{13}\right]$ trimers of edge-sharing $M \mathrm{O}_{6}$ octahedra. There are five different isomers of Keggin ions $(\alpha-, \beta-, \gamma-, \delta$ - and $\varepsilon$-; also called rotational isomers), which differ from each other by the rotational orientations of the $\left[M_{3} \mathrm{O}_{13}\right]$ units (Baker \& Figgis, 1970). It is remarkable that no simple analogues of Keggin clusters have been observed in minerals so far. The crystal structure of kegginite named by Kampf et al. (2017c) in honour of J. F. Keggin contains a monocapped $\varepsilon$-Keggin anion with the chemical composition $\left[\mathrm{As}^{5+} \mathrm{V}_{12} \mathrm{O}_{40}(\mathrm{VO})\right]^{12-}$ [Fig. 1(c)]. The metal skeleton of the $\varepsilon$-Keggin isomer is a truncated tetrahedron or Laves polyhedron shaped by four triangular and four hexagonal faces. In the monocapped version observed in kegginite, one of the hexagonal faces is capped by the additional $\mathrm{V}^{5+}$ cation. Kampf et al. (2017c) emphasizes that kegginite is the first example of a structure, either synthetic or natural, with a monocapped $\varepsilon$-Keggin isomer. It is worth noting that polymerized $\varepsilon$-Keggin ions have at least two representatives in the kingdom of minerals. The crystal structure of zunyite, $\mathrm{Al}_{13} \mathrm{Si}_{5} \mathrm{O}_{20}(\mathrm{OH}, \mathrm{F})_{18} \mathrm{Cl}$ (Baur \& Ohta, 1982), contains $\left[\mathrm{AlAl}_{12}(\mathrm{O}, \mathrm{OH}, \mathrm{F})_{40}\right]$ anions that share corners to form an open framework accommodating the [ $\left.\mathrm{Si}_{5} \mathrm{O}_{16}\right]$ tetramers of $\mathrm{SiO}_{4}$ tetrahedra. A similar framework has been observed in murataite-( $\mathrm{Y}),(\mathrm{Y}, \mathrm{Na})_{6} \mathrm{Zn}\left(\mathrm{Zn}, \mathrm{Fe}^{3+}\right)_{4^{-}}$ ( Ti,Nb,Na $)_{12} \mathrm{O}_{29}(\mathrm{O}, \mathrm{F}, \mathrm{OH})_{10} \mathrm{~F}_{4}$, where the $\varepsilon$-Keggin ions have the idealized formula $\left\{\mathrm{ZnTi}_{12} \mathrm{O}_{40}\right\}$ and consist of central $\mathrm{ZnO}_{4}$ tetrahedra surrounded by trimers of $\mathrm{TiO}_{6}$ octahedra (Ercit \& Hawthorne, 1995). The synthetic analogue of murataite-(Y) and the titanate-based ceramics of the murataite-pyrochlore series have a high potential as matrices for the immobilization of high-level radioactive waste products with complex chemical composition (Morgan \& Ryerson, 1982; Laverov et al., 1998; Krivovichev et al., 2010; Pakhomova et al., 2013, 2016).

A natural example of the bicapped $\alpha$-isomer of the Keggin ion was recently discovered in bicapite, another lowtemperature mineral from the Colorado Plateau (Kampf et al., 2019). The POM cluster has the formula $\left[\mathrm{H}_{2} \mathrm{PV}^{5+}{ }_{12} \mathrm{O}_{40}\left(\mathrm{~V}^{5+} \mathrm{O}\right)_{2}\right]^{7-}$ and consists of a central (disordered) $\mathrm{PO}_{4}$ tetrahedron surrounded by $12 \mathrm{VO}_{6}$ octahedra to form the $\alpha-\left\{\mathrm{PV}^{5+}{ }_{12} \mathrm{O}_{40}\right\}$ Keggin ion capped by two vanadyl $\mathrm{V}^{5+} \mathrm{O}$ groups with $\mathrm{V}^{5+}$ in a tetragonal pyramidal coordination [Fig. 1(d)]. In the skeletal representation, the $12 \mathrm{~V}$ atoms form around the central $\mathrm{P}$ heteroatom a cuboctahedron with eight triangular and six square faces. Two additional $\mathrm{V}$ atoms are located above two opposite square faces. We note that bicapped vanadophosphate anions are known in synthetic chemistry (Nakamura et al., 2006).

Sherwoodite is an interesting example of a structure with the Keggin-related $\left[\mathrm{AlV}^{4+}{ }_{2} \mathrm{~V}^{5+}{ }_{12} \mathrm{O}_{40}\right]^{9-} \mathrm{POM}$ cluster with the central atom in an octahedral coordination [Fig. 2(a)]. It consists of $14\left(\mathrm{VO}_{6}\right)$ octahedra surrounding a central $\mathrm{AlO}_{6}$ octahedron. Its skeletal representation corresponds to the bicapped $\alpha$-isomer of a Keggin anion and thus is identical to that of bicapite. However, the octahedral coordination of the central $\mathrm{Al}^{3+}$ cation makes it geometrically and topologically different from Keggin anions. It is of interest that the sherwoodite type of POM clusters has a very few synthetic analogues. In fact, the crystal structure of sherwoodite was reported by Evans \& Konnert (1978) before similar POM structures were prepared synthetically [the mineral itself was found even earlier (Thompson et al., 1958)]. Müller et al. (1991) reported the crystal structure of $\mathrm{K}_{7}\left[\mathrm{~V}^{4+}{ }_{2} \mathrm{~V}^{5+}{ }_{12-}\right.$ $\left.\mathrm{As}^{5+} \mathrm{O}_{40}\right] \cdot 12 \mathrm{H}_{2} \mathrm{O}$ containing the $\left[\mathrm{V}^{4+}{ }_{2} \mathrm{~V}^{5+}{ }_{12} \mathrm{As}^{5+} \mathrm{O}_{40}\right]^{7-}$ cluster, which the authors described as the 'model for vanadium minerals formed by weathering'. The rather unusual octahedral coordination of the central $\mathrm{As}^{5+}$ cation is enforced by the topological requirements. Later, a similar type of a 15-nuclear octahedral cluster was reported in the crystal structure of $\mathrm{K}_{2} \mathrm{Na}_{6}\left[\mathrm{~V}^{4+}{ }_{2} \mathrm{~V}^{5+}{ }_{12} \mathrm{Ge}^{4+} \mathrm{O}_{40}\right] \cdot 10 \mathrm{H}_{2} \mathrm{O}$ with the $\mathrm{Ge}^{4+}$ cation as a central heteroatom (Bi et al., 2006; Monakhov et al., 2015). As far as we know, no synthetic compound with trivalent cations
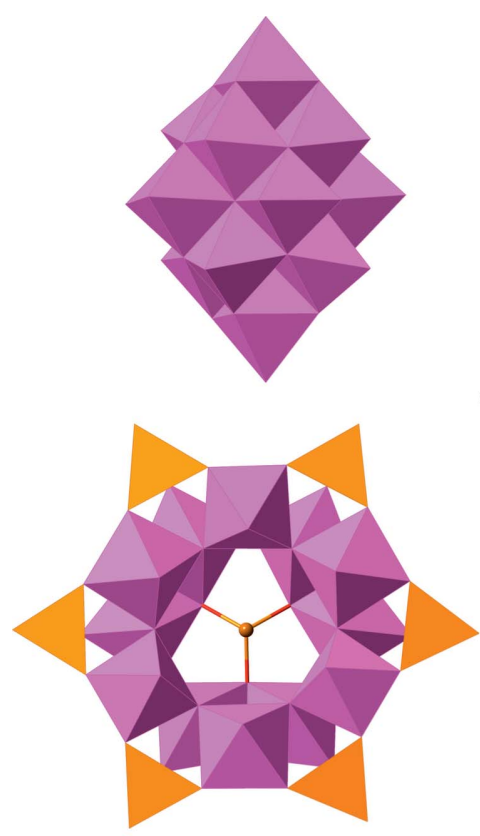

(a)
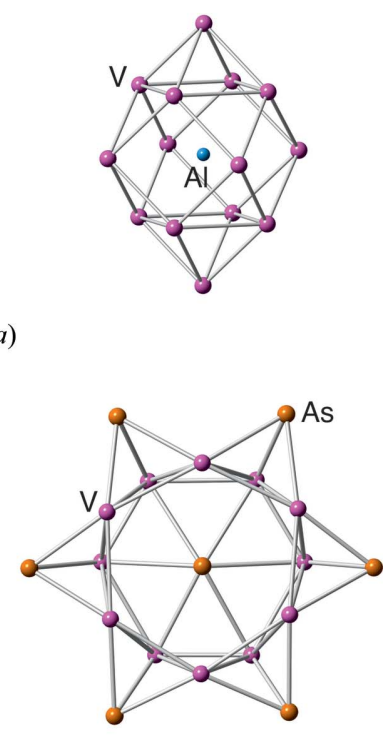

(b)

Figure 2

Polyoxometalate clusters in minerals shown in polyhedral (left) and skeletal (right) representations: the $\left[\mathrm{AlV}^{4+}{ }_{2} \mathrm{~V}^{5+}{ }_{12} \mathrm{O}_{40}\right]^{9-}$ cluster in sherwoodite $(a)$ and the $\left[\mathrm{As}^{3+} \mathrm{V}^{4+}{ }_{2} \mathrm{~V}^{5+}{ }_{10} \mathrm{As}^{5+}{ }_{6} \mathrm{O}_{51}\right]^{7-}$ cluster in morrisonite $(b)$. 
(such as $\mathrm{Al}^{3+}$ in sherwoodite) as heteroatoms in this POM cluster type has been described in the literature. In nature, sherwoodite was found in the Colorado uranium-vanadium mineral deposits as an oxidation product of earlier low-valent V minerals (Thompson et al., 1958).

From the viewpoint of structural complexity, kegginite, bicapite and sherwoodite belong to the group of complex or very complex minerals and, in this respect, do not differ much from the pascoite-group minerals. In contrast, the minerals of the vanarsite group (morrisonite, packratite, gatewayite, vanarsite, and lumsdenite; Kampf et al., 2016b, 2020c) are the champions in complexity among natural polyoxovanadates (Table 2). In particular, morrisonite has 13558.354 bits of Shannon information per unit cell and, after ewingite (see below), is the second most complex mineral known so far. The vanarsite-group minerals contain unique and previously unknown type of the V-As POM cluster with the composition $\left[\mathrm{As}^{3+} \mathrm{V}_{12} \mathrm{As}^{5+}{ }_{6} \mathrm{O}_{51}\right]$. The cluster consists of $12 \mathrm{VO}_{6}$ octahedra forming wheel- or corona-shaped unit centred by $\mathrm{As}^{3+}$ cation in a trigonal-pyramidal coordination (due to the stereoactivity of a lone-electron pair) and surrounded by six $\mathrm{As}^{5+} \mathrm{O}_{4}$ tetrahedra [Fig. 2(b)]. Similarly to decavanadates described above, the vanarsite-group minerals form from low-temperature aqueous solutions with $\mathrm{V}$ and As derived from the oxidation of primary unoxidized phases.

As it was noted previously, caseyite contains two different topological types of POM clusters. Fig. 3(a) shows the flat $\left[\left(\mathrm{V}^{5+} \mathrm{O}_{2}\right) \mathrm{Al}_{10-x}(\mathrm{OH})_{20-2 x}\left(\mathrm{H}_{2} \mathrm{O}\right)_{18-2 x}\right]^{11+}$ polycation formed by the disk of six $\mathrm{AlO}_{6}$ octahedra and one $\mathrm{VO}_{6}$ octahedron

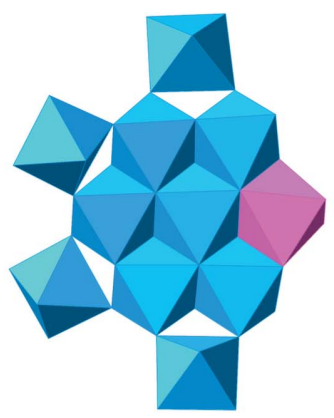

(a)
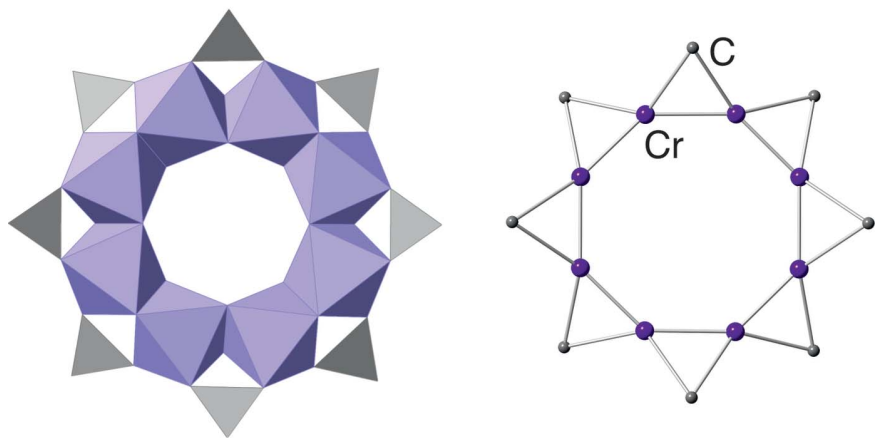

(b)

Figure 3

Planar polyoxometalate clusters in minerals shown in polyhedral (left) and skeletal (right) representations: the $\left[\left(\mathrm{V}^{5+} \mathrm{O}_{2}\right) \mathrm{Al}_{10-x}(\mathrm{OH})_{20-}\right.$ $\left.{ }_{2 x}\left(\mathrm{H}_{2} \mathrm{O}\right)_{18-2 x}\right]^{11+}$ cluster in caseyite $(a)$ and the $\left[\mathrm{Cr}^{3+}{ }_{8}(\mathrm{OH})_{16}\left(\mathrm{CO}_{3}\right)_{8}\right]^{8-}$ cluster in putnisite $(b)$. sharing common edges. The disk is further incrustated by four Al-centred octahedra that are corner-linked to the Al octahedra of the disk. The caseyite polycation is thus topologically intermediate between the Anderson seven-nuclear POM anion consisting of seven edge-sharing octahedra and the flat$\mathrm{Al}_{13}$ polyoxometalate cation $\left[\mathrm{Al}_{13}(\mathrm{OH})_{24}\left(\mathrm{H}_{2} \mathrm{O}\right)_{24}\right]^{15+}$ first reported in the crystal structure of $\left[\mathrm{Al}_{13}(\mathrm{OH})_{24^{-}}\right.$ $\left.\left(\mathrm{H}_{2} \mathrm{O}\right)_{24}\right] \mathrm{Cl}_{15} \cdot 13 \mathrm{H}_{2} \mathrm{O}$ (Seichter et al., 1998). Though there are no known minerals that contain isolated flat $\mathrm{Al}_{13}$ clusters, the crystal structure of cadwaladerite, $\mathrm{Al}_{2}\left(\mathrm{H}_{2} \mathrm{O}\right)(\mathrm{OH})_{4}$-$n\left(\mathrm{Cl}, \mathrm{OH}, \mathrm{H}_{2} \mathrm{O}\right)($ Peterson et al., 2019; also known as 'lesukite' (Vergasova et al., 1997), which is now a discredited name) is based upon an open framework of polymerized $\left[\mathrm{Al}_{13}(\mathrm{OH})_{24}\left(\mathrm{H}_{2} \mathrm{O}\right)_{24}\right]^{15+}$ cations. It is noteworthy that cadwaladerite ('lesukite') was detected in a broad range of geochemical and technological environments: it forms as a result of transformation of young basalts by microorganisms on volcanoes (Kutuzova et al., 2004, 2006; Filatov et al., 2004, 2012) and was found in burned coal mines (Witzke, 1997) and in corrosion products of nuclear reactor fuels (Neumann et al., 2018).

\subsection{Polyoxocuprates}

The term 'polyoxocuprates' was coined by Müller et al. (1991) to denote cluster-like polyanions formed by the polymerization of the $\mathrm{CuO}_{4}$ square-like units in the crystal structure of $\mathrm{BaCuO}_{2}$. The recent achievements in the field were summarized by Kondinski \& Monakhov (2017), who recognized the presence of POM Cu clusters in minerals, e.g. of the $\left[\mathrm{Cu}_{12}(\mathrm{OH})_{24}\right]$ clusters in the cavities of the zeolite aluminosi- (a)

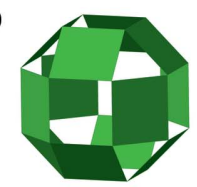

(d)

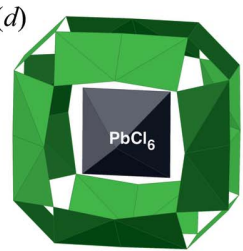

(g)

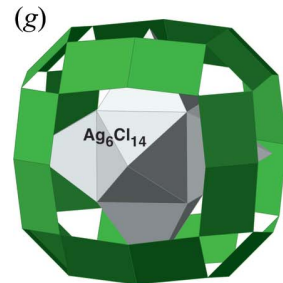

(b)

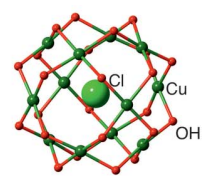

(e)

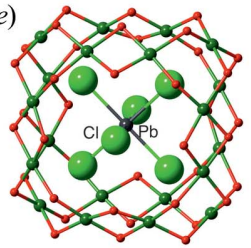

(h)

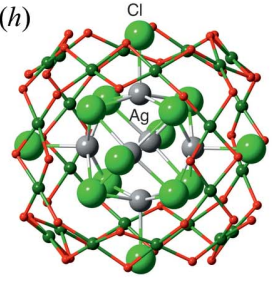

(c)

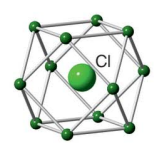

(f)

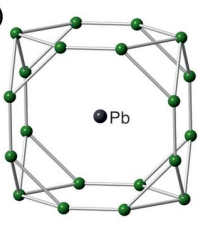

(i)

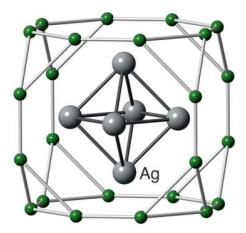

Figure 4

$\left[\mathrm{Cu}_{n}(\mathrm{OH})_{2 n}\right]^{0}$ clusters in minerals: the $\left[\mathrm{Cu}_{12}(\mathrm{OH})_{24}\right]^{0}$ cluster in tschörtnerite shown in polyhedral $(a)$, ball-and-stick $(b)$ and skeletal $(c)$ representations; the $\left[\mathrm{Cu}_{20}(\mathrm{OH})_{40}\right]^{0}$ cluster in cumengeite $(d, e, f)$; the $\left[\mathrm{Cu}_{24}(\mathrm{OH})_{48}\right]^{0}$ cluster in boleite $(g, h, i)$. Legend: $\mathrm{Cu}=$ dark-green; $\mathrm{O}=$ red; $\mathrm{Pb}=$ black; $\mathrm{Ag}=$ grey; $\mathrm{Cl}=$ light-green. 
licate framework in tschörtnerite. At least three different POM cage topologies with the chemical composition $\left[\mathrm{Cu}_{n}(\mathrm{OH})_{2 n}\right]$ are known in natural minerals. In all the reported cases, the $\left\{\mathrm{Cu}_{n}(\mathrm{OH})_{2 n}\right\}$ cages encapsulate specific chemical moieties and thus can be considered as special types of hostguest complexes. The cages are formed by polymerization of $\left\{\mathrm{Cu}(\mathrm{OH})_{4}\right\}$ square units by sharing edges and corners. In the crystal structure of tschörtnerite, $12 \mathrm{Cu}$ atoms comprise a cuboctahedron [Fig. 4(c)] with $24 \mathrm{OH}$ groups associated with 24 edges [Fig. 4(b)]; the $\left(\mathrm{Cu}(\mathrm{OH})_{4}\right)$ squares share corners only. The resulting $\left[\mathrm{Cu}_{12}(\mathrm{OH})_{24}\right]$ cage encapsulates a disordered arrangement of $\mathrm{Cl}^{-}$anions and $\mathrm{H}_{2} \mathrm{O}$ molecules. In the crystal structure of cumengeite, $20 \mathrm{Cu}$ centres form a flattened cuboctahedron with the face symbol $8^{2} 6^{4} 3^{8}$ (two octagonal, four hexagonal and eight trigonal faces) [Fig. 4(f)]. In terms of square-like $\mathrm{Cu}$-centred units, the cluster is built from eight dimers of edge-sharing squares that share corners with four additional squares [Figs. $4(d)$ and $4(e)$ ]. The interior of the $\left[\mathrm{Cu}_{20}(\mathrm{OH})_{40}\right]$ cage is occupied by the $\mathrm{PbCl}_{6}$ octahedron. The crystal structure of boleite contains a highly symmetric $\left[\mathrm{Cu}_{24}(\mathrm{OH})_{48}\right]$ cuboctahedral cluster with an $8^{6} 3^{8}$ metal skeleton [Fig. 4(i)]. The cage is built solely from 12 dimers of edge-sharing $\mathrm{Cu}(\mathrm{OH})_{4}$ units geometrically associated with the 12 edges of a cube [Figs. $4(g)$ and $4(h)]$. In boleite, the cluster accommodates a superoctahedral $\left[\mathrm{Ag}_{6} \mathrm{Cl}_{14}\right]$ arrangement of six $\mathrm{AgCl}_{5}$ square pyramids.

All minerals with the $\mathrm{Cu}$-based polyhydroxo anions crystallize from low-temperature hydrothermal solutions, either at the latest stages of hydrothermal activity (tschörtnerite) or in the oxidation zones of copper-lead mineral deposits (cumengeite, boleite, pseudoboleite). Note that tschörtnerite is extremely complex (5421.227 bits/cell; Table 3), due to the high complexity of its zeolite framework with five types of aluminosilicate cages occupied by various interstitial species (Krivovichev, 2013). Cumengeite, boleite and pseudoboleite belong to the group of complex and very complex structures (800-1100 bits/cell).

Most of the POM clusters in minerals are usually associated with crystallization from aqueous solutions. Britvin et al. (2020) reported recently on the discovery of two fumarolic minerals, arsmirandite and lehmannite, which formed directly from volcanic gases. The basic structural unit in both structures is a novel nanoscale $(\sim 1.5 \mathrm{~nm}$ across) polyoxocuprate cluster with the composition $\left\{\left[M \mathrm{Cu}_{12} \mathrm{O}_{8}\right]\left(\mathrm{AsO}_{4}\right)_{8}\right\}\left(M=\mathrm{Fe}^{3+}\right.$

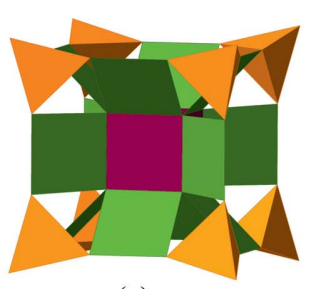

(a)

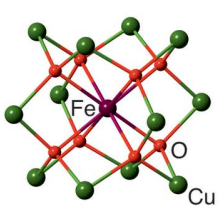

(b)

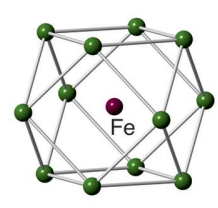

(c)
Figure 5

The $\left[\mathrm{Cu}_{12}{ }^{2+} \mathrm{Fe}^{3+} \mathrm{O}_{8}\left(\mathrm{AsO}_{4}\right)_{8}\right]^{13-}$ cluster in arsmirandite shown in polyhedral representation $(a)$, its $\left[\mathrm{O}_{8} \mathrm{Cu}_{12} \mathrm{Fe}\right]$ metal-oxide core $(b)$, and the arrangement of metal atoms $(c)$. and $\mathrm{Ti}^{4+}$, for arsmirandite and lehmannite, respectively; Fig. 5). The most peculiar feature of the cluster is the presence of $\mathrm{Fe}^{3+}$ (arsmirandite) or $\mathrm{Ti}^{4+}$ (lehmannite) in cubic coordination, which is the first observation of such configurations in minerals. Each $\mathrm{O}$ atom of the $\left(\mathrm{MO}_{8}\right)$ cube is further coordinated by three $\mathrm{Cu}^{2+}$ cations that have square-planar geometry by the $\mathrm{O}$ atoms of the $\mathrm{AsO}_{4}$ groups. The metal-oxide core of the nanocluster can also be represented in terms of oxocentered $\left(\mathrm{OCu}_{3} M\right)$ tetrahedra that form an eightfold unit, which can be considered as a fragment of the crystal structure of fluorite, if the latter is described as a framework of $\mathrm{FCa}_{4}$ tetrahedra (Krivovichev et al., 2013). The metal skeleton of the $\left[\mathrm{O}_{8} M \mathrm{Cu}_{12}\right]$ core is a $\mathrm{Cu}_{12}$ cuboctahedron encapsulating a tetravalent $M$ heteroatom. From the topological point of view, the POM cluster in arsmirandite and lehmannite is identical to the polyoxopalladate $\left[\mathrm{H}_{6} \mathrm{Pd}_{13} \mathrm{O}_{8}\left(\mathrm{AsO}_{4}\right)_{8}\right]^{8-}$ nanoclusters first reported in the crystal structure of $\mathrm{Na}_{8}\left[\mathrm{Pd}_{13} \mathrm{O}_{8}\left\{\mathrm{AsO}_{3}\right.\right.$ $\left.(\mathrm{OH})\}_{6}\left(\mathrm{AsO}_{4}\right)_{2}\right] \cdot 42 \mathrm{H}_{2} \mathrm{O}$ (Chubarova et al., 2008). The clusters with the same metal-oxide core were later found in a large number of structures recently reviewed by Yang \& Kortz (2018). As far as we know, arsmirandite and lehmannite are unique examples of the POM mineral structures that crystallized from gases and contain no $\mathrm{H}_{2} \mathrm{O}$. The discovery of these mineral species points out to the importance of polynuclear clusters as possible forms of metal transport by volcanic gases, which was first suggested by Filatov et al. (1992). Despite the high nuclearity and nanoscale size of their POM clusters, arsmirandite and lehmannite belong to the group of structures with intermediate complexity (Table 3 ).

The widespread occurrence of cuboctahedral $\alpha$-Keggin-like arrangements of metal atoms in mineral structures is further illustrated by the recent discovery of the $\left[\mathrm{Mg}_{8} \mathrm{Cu}_{12}\left(\mathrm{PO}_{4}\right)\right.$ $\left.\left(\mathrm{CO}_{3}\right)_{4}(\mathrm{OH})_{24}\left(\mathrm{H}_{2} \mathrm{O}\right)_{20}\right]^{5+}$ polycation in ramazzoite (Kampf et

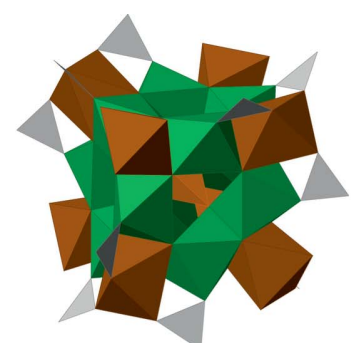

(a)

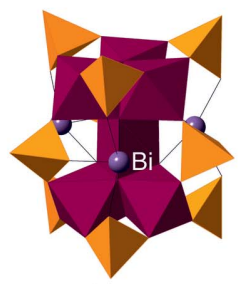

(d)

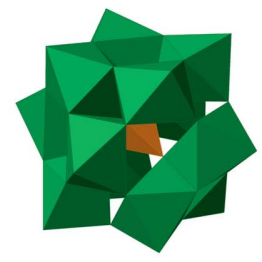

(b)

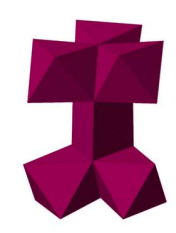

(e)

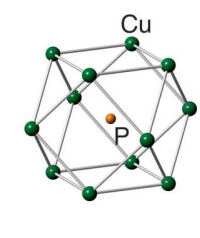

(c)

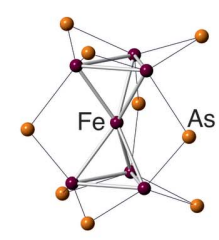

$(f)$
Figure 6

The $\left[\mathrm{Mg}_{8} \mathrm{Cu}_{12}\left(\mathrm{PO}_{4}\right)\left(\mathrm{CO}_{3}\right)_{4}(\mathrm{OH})_{24}\left(\mathrm{H}_{2} \mathrm{O}\right)_{20}\right]^{5+}$ cluster in ramazzoite $(a)$, its copper phosphate core $(b)$ and the $\mathrm{Cu}-\mathrm{P}$ substructure $(c)$; the $\left[\mathrm{Bi}_{3} \mathrm{Fe}_{7}\left(\mathrm{AsO}_{4}\right)_{9} \mathrm{O}_{6}(\mathrm{OH})_{2}\right]^{5-}$ cluster in bouazzerite $(d)$, its ferric oxide core $(e)$ and the skeletal representation of the $\mathrm{Fe}-\mathrm{As}$ substructure $(f)$. 
al., 2018b). The core of the polycation is the $\left\{\mathrm{PCu}_{12} \mathrm{O}_{40}\right\} \alpha$ Keggin cluster formed by a central $\mathrm{PO}_{4}$ tetrahedron and 12 $\mathrm{CuO}_{6}$ octahedra [Figs. 6(a), 6(b) and 6(c)]. The cuprophosphate core is surrounded by $\mathrm{MgO}_{6}$ octahedra and disordered $\mathrm{CO}_{3}$ groups that complete the cluster architecture. Ramazzoite was found in the Monte Ramazzo mine, Genova, Genova Province, Liguria, Italy, where it crystallized from lowtemperature $\left(<50^{\circ} \mathrm{C}\right)$ aqueous solutions at $\mathrm{pH}$ from 6 to 12 and low fugacity of $\mathrm{CO}_{2}$ (Kampf et al., 2018b). With 1848.162 bits of Shannon information per unit cell, ramazzoite is classified as a very complex mineral.

\subsection{Miscellaneous}

Despite the diversity of polyoxotungstate clusters discovered synthetically, there is only one mineral, ophirite, that is based on W-containing POM anions. In its structure, two trilacunary (i.e. with three missing octahedra) Keggin ions, $\left[\mathrm{Fe}^{3+} \mathrm{W}_{9} \mathrm{O}_{34}\right]^{11-}$, are linked by the rhombus-like block of four edge-sharing $M \mathrm{O}_{6}$ octahedra $(M=\mathrm{Zn}, \mathrm{Mn})$ to form a sandwich-type POM $\left[\mathrm{Zn}_{2} \mathrm{Mn}^{3+}{ }_{2}\left(\mathrm{H}_{2} \mathrm{O}\right)_{2}\left(\mathrm{Fe}^{3+} \mathrm{W}_{9} \mathrm{O}_{34}\right)_{2}\right]^{12-}$ (Fig. 7). Ophirite was discovered by Kampf et al. (2014c) in the Ophir Hill Consolidated Mine, Ophir district, Oquirrh Mountains, Tooele County, Utah, USA, as a mineral deposited from late acidic and oxidizing hydrothermal solutions that reacted with scheelite $\left(\mathrm{CaWO}_{4}\right)$ and pyrite as the sources of $\mathrm{W}$ and $\mathrm{Fe}$, respectively. Due to its unusual character and uniqueness, ophirite was named by the International Mineralogical Association (IMA) as the Mineral of the Year 2014 (Krivovichev, 2015).

Fig. 3(b) shows the flat $\left[\mathrm{Cr}^{3+}{ }_{8}(\mathrm{OH})_{16}\left(\mathrm{CO}_{3}\right)_{8}\right]^{8-}$ anion found in the crystal structure of putnisite, a rare mineral from the Polar Bear peninsula, Western Australia (Elliott et al., 2014). In this cluster, eight $\mathrm{Cr}^{3+}$-centred octahedra share edges to form a ring, which is decorated by eight $\mathrm{CO}_{3}$ triangles. As far as we know, this wheel-shaped POM cluster has no analogues among minerals and synthetic compounds. Putnisite is a secondary mineral formed during the oxidation of the primary

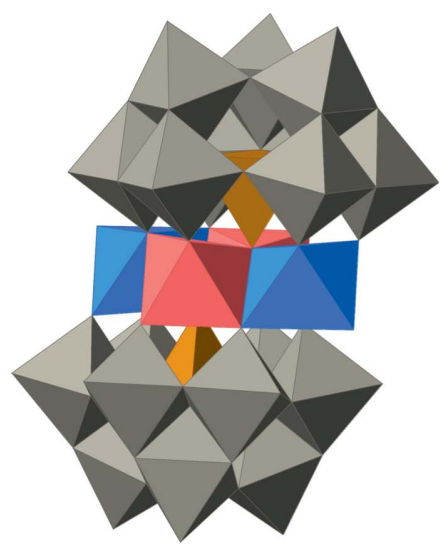

(a)
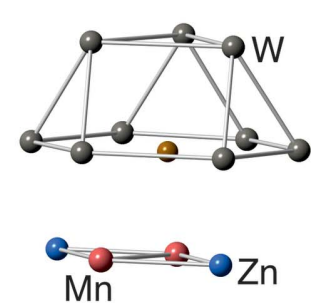

$\mathrm{Fe}$

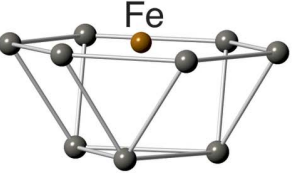

(b)
Figure 7

The $\left[\mathrm{Zn}_{2} \mathrm{Mn}^{3+}{ }_{2}\left(\mathrm{H}_{2} \mathrm{O}\right)_{2}\left(\mathrm{Fe}^{3+} \mathrm{W}_{9} \mathrm{O}_{34}\right)_{2}\right]^{12-}$ cluster in ophirite $(a)$ and its skeletal representation $(b)$. sulfide-bearing rocks. The mineral is very complex possessing 2932.730 bits of information per reduced unit cell.

Bouazzerite and whitecapsite are two $\mathrm{Fe}$ arsenates from oxidation zones of mineral deposits. The crystal structures of both minerals possess topologically identical $\left[M^{3+}{ }_{3} \mathrm{Fe}_{7^{-}}\right.$ $\left(\mathrm{AsO}_{4}\right)_{9} \mathrm{O}_{8-n}(\mathrm{OH})_{n}$ ] polyanions, where $M=\mathrm{Bi}$ and $n=2$ for bouazzerite, and $M=\mathrm{Sb}$ and $n=0$ for whitecapsite [Figs. $6(d)$, $6(e)$ and $6(f)]$. The core of the cluster is a seven-nuclear ferric oxide unit consisting of two trimers of edge-sharing $\left(\mathrm{Fe}^{3+} \mathrm{O}_{6}\right)$ octahedra linked via the unusual $\mathrm{Fe}^{3+} \mathrm{O}_{6}$ trigonal prism that had not been observed in any other mineral. The unit is decorated by nine $\mathrm{AsO}_{4}$ tetrahedra and three $M^{3+}$ cations with an asymmetric coordination mode induced by the stereoactivity of the $s^{2}$ electron pairs. Similarly to the cubic coordination of $\mathrm{Ti}^{4+}$ and $\mathrm{Fe}^{3+}$ cations in lehmannite and arsmirandite, the trigonal prismatic coordination of the central $\mathrm{Fe}^{3+}$ cation in bouazzerite and whitecapsite is enforced by the geometrical requirements imposed by the overall cluster topology (Brugger et al., 2007). The $\mathrm{Fe}_{7}$ skeleton of the cluster in the two minerals is similar to the $\mathrm{Pt}_{7}$ core of the $\left[\mathrm{Pt}_{7} \mathrm{O}_{6}\left(\mathrm{NO}_{2}\right)_{12}\right]^{8-}$ cluster in the crystal structure of $\mathrm{K}_{8}\left[\mathrm{Pt}_{7} \mathrm{O}_{6}\left(\mathrm{NO}_{2}\right)_{12}\right]$ (Privalov et al., 1991), but the central $\mathrm{Pt}^{4+}$

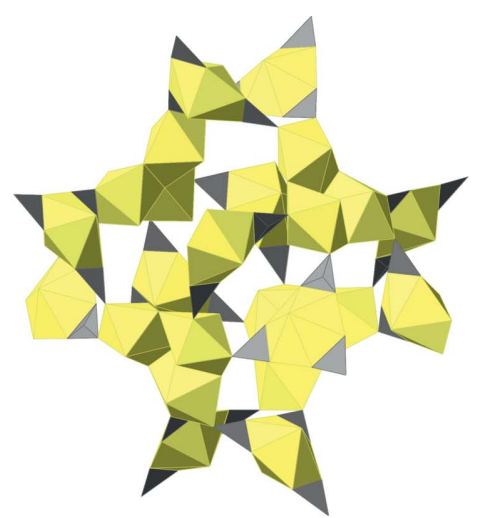

(a)

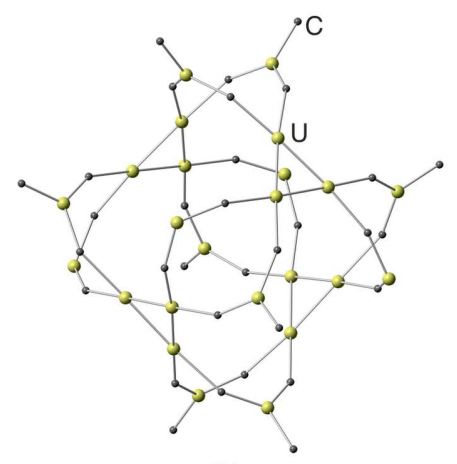

(b)

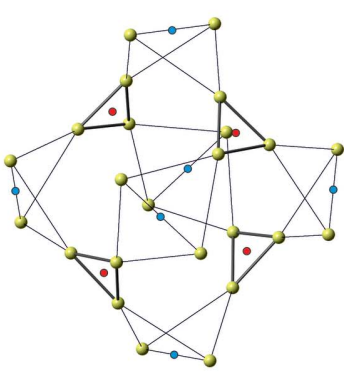

(c)

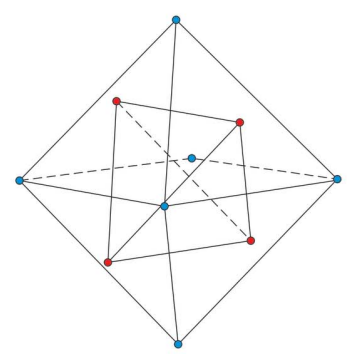

(d)
Figure 8

The $\left[\left(\mathrm{UO}_{2}\right)_{24}\left(\mathrm{CO}_{3}\right)_{30} \mathrm{O}_{4}(\mathrm{OH})_{12}\left(\mathrm{H}_{2} \mathrm{O}\right)_{8}\right]^{32-}$ cluster in ewingite $(a)$, its skeletal representation $(b)$, the $\mathrm{U}$ core $(c$; the $\mathrm{U}$... U contacts shorter than $4 \AA$ are shown as thick black lines; those between 4 and $6.2 \AA$ as thin black lines; red and blue dots indicate centres of the $\mathrm{U}_{3}$ trimers and midpoints of the shared $\mathrm{U} \cdots \mathrm{U}$ edges of the $\mathrm{U}_{4}$ dihedra, respectively), and the arrangements of the red and blue dots that correspond to the intersection of tetrahedron and octahedron, respectively $(d)$. 
ion in the latter has an octahedral and not trigonal prismatic coordination. Both structures are very complex with the crystal structure of bouazzerite being more than twice as complex (6062.598 bits/cell) than that of whitecapsite (2811.809 bits/cell). The different complexity of the two structures is the result of the difference in their symmetry. Bouazzerite is monoclinic $\left(P 2_{1} / n\right)$ with the trivial symmetry of the POM cluster, whereas whitecapsite is hexagonal $\left(\mathrm{Pb}_{3} / \mathrm{m}\right)$ and the cluster has a $\overline{6}$ point-symmetry group.

Ewingite is the Earth's most complex mineral reported so far with estimated complexity of 23477.507 bits/cell. The mineral was found as golden-yellow crystals formed on a damp wall of the old Plavno mine of the Jáchymov ore district, western Bohemia, Czech Republic (Olds et al., 2017). Ewingite crystallized from low-temperature uranyl-bearing aqueous solutions. Its crystal structure contains a 54-nuclear $(24 \mathrm{U}+$ $30 \mathrm{C})$ uranyl carbonate cluster $\left[\left(\mathrm{UO}_{2}\right)_{24}\left(\mathrm{CO}_{3}\right)_{30} \mathrm{O}_{4}(\mathrm{OH})_{12^{-}}\right.$ $\left.\left(\mathrm{H}_{2} \mathrm{O}\right)_{8}\right]^{32-}$ shown in Fig. 8(a). Its skeletal representation [Fig. 8(b)] emphasizes the presence of four $\mathrm{U}_{3}$ triads (with the U-U distances shorter than $4 \AA$ ) that correspond to trimers of three $\left(\mathrm{UO}_{2}\right)_{5}$ pentagonal bipyramids sharing the same equatorial $\mathrm{O}$ atom. Two other building units are the $\left(\mathrm{UO}_{2}\right)\left(\mathrm{CO}_{3}\right)_{3}$ and $\left(\mathrm{UO}_{2}\right)\left(\mathrm{CO}_{3}\right)_{2}\left(\mathrm{H}_{2} \mathrm{O}\right)_{2}$ hexagonal bipyramids. The visual complexity of the cluster architecture can further be reduced by leaving only $\mathrm{U}$ atoms and the addition of the $\mathrm{U}-$ $\mathrm{U}$ links corresponding to the $\mathrm{U}-\mathrm{U}$ distances in between 4 and $6.2 \AA$ [Fig. 8(c)]. The resulting graph can be considered as consisting of four $\mathrm{U}_{3}$ trimers ( $U-\mathrm{U}<4 \AA$ ) and six $\mathrm{U}_{4}$ dihedra of two edge-sharing $\mathrm{U}_{3}$ triangles $(\mathrm{U}-\mathrm{U}=4.0-6.2 \AA)$. The centres of the trimers and the dihedra [denoted by red and blue dots in Fig. 8(c)] form a tetrahedron and an octahedron, respectively, with six tetrahedral edges arranged in correspondence to six octahedral vertices [Fig. $8(d)$ ]. Such a relation between the tetrahedral and octahedral graphs is known in graph theory as an edge-to-vertex duality. The octahedral graph can be obtained from the tetrahedral graph $K_{4}$ by associating a vertex with each edge of the $K_{4}$ graph and connecting two vertices with an edge if the corresponding edges of $K_{4}$ have a vertex in common (Gross \& Yellen, 2006). Therefore the topology of the uranyl carbonate cluster in ewingite, in addition to its extreme complexity, has the interesting property of being self-edge-to-vertex dual.

\section{Summary and perspectives}

In this review, we described 15 different types of POM nanoscale-size clusters in minerals that occur in 42 different mineral species. This number is relatively small and constitutes less than one percent of all minerals currently recognized by the IMA [for March 2020, there are 5575 valid mineral species (Pasero, 2020)]. The topological diversity of POM clusters in minerals is rather restricted compared to the multitude of moieties reported for synthetic compounds, but the lists of synthetic and natural POMs do not overlap completely. There are several natural metal-oxo clusters that have no close chemical or topological analogues in synthetic chemistry (e.g. clusters in the vanarsite-group minerals, bouazzerite and whitecapsite, putnisite and ewingite). The popularity of cuboctahedral (or Keggin-related) topologies of POM minerals is remarkable and points to the special stability of these motifs under environmental conditions.

In most cases, the existence of the POM clusters is governed by the asymmetry of the bond-strength distributions around cluster-forming high-valent $\mathrm{Me}^{m+}$ transition metal cations that results in the formation of double or triple $\mathrm{Me}^{m+}$ bonds to the oxygen atoms located on the cluster surfaces. This feature prevents further polymerization of $\mathrm{MeO}_{n}$ polyhedra and stabilizes the clusters as finite polyhedral complexes. This mechanism is valid for the natural POMs as well, which have the surface truncated by valence-satisfied $\mathrm{O}$ atoms (e.g. in decavanadate clusters) or $\mathrm{H}_{2} \mathrm{O}$ groups (e.g. in natrophosphate). The special case is exemplified by the polyoxocuprate clusters in arsmirandite and lehmannite, where they are immersed into a deficient $\mathrm{NaCl}$ matrix that stabilizes the cluster surface via ionic interactions (Britvin et al., 2020). Similarly to synthetic compounds, in the crystal structures of natural POMs, the clusters are held together via hydrogen bonds and ionic bonds to alkaline or alkaline earth cations that are much weaker than the $\mathrm{Me}-\mathrm{O}$ bonds inside the clusters. Again, by analogy to synthetic POMs, the crystallization of natural POMs is the result of self-assembly of metal-oxo clusters already pre-existing in solutions or gases, which points to the importance of polynuclear complexes in geological environments that is not always well recognized in modern geochemistry.

The chemical diversity of natural POM clusters deserves special attention. Twenty-six minerals out of 42 considered above contain $\mathrm{V}$ as an essential mineral-forming component. It is rather surprising that, in contrast to synthetic chemistry, no isolated POM clusters have been reported for Mo minerals. It should be noted that there exists a heteropolymolybdate family of minerals (Kampf et al., 2012b, and references therein) but, in their structures, molybdate units are tightly bonded by octahedra of high-valent metal cations to form three-dimensional frameworks, which precludes their consideration in this review. We may expect that, in the future, detailed investigations of the post-mining mineralogy of Mo deposits will reveal mineral phases containing polyoxomolybdate anions. In general, the discovery of POMs in the crystal structures of mineral phases may lead to the reconsideration of the existing geochemical concepts of the forms of transport, migration and mobility of metals in nature (Rustad, 2010; Nyman, 2018; Friis \& Casey, 2018). The most common mode of occurrence of minerals with POMs clusters is their crystallization from low-temperature aqueous solutions, quite in agreement with their preparation in laboratory experiments. The only exception is arsmirandite and lehmannite that form directly from volcanic gases.

One of the interesting features of POM cluster topologies in minerals is the presence of unusual coordination of metal atoms (as a rule, central atoms in the clusters) enforced by the topological restraints imposed upon the cluster geometry. The examples are the cubic coordination of $\mathrm{Fe}^{3+}$ and $\mathrm{Ti}^{4+}$ ions in arsmirandite and lehmannite, respectively, and the trigonal 
prismatic coordination of $\mathrm{Fe}^{3+}$ in bouazzerite and whitecapsite. A similar example from synthetic chemistry is the octahedral coordination of $\mathrm{As}^{5+}$ in the sherwoodite-type cluster in $\mathrm{K}_{7}\left[\mathrm{~V}^{4+}{ }_{2} \mathrm{~V}^{5+}{ }_{12} \mathrm{As}^{5+} \mathrm{O}_{40}\right] \cdot 12 \mathrm{H}_{2} \mathrm{O}$ (Müller et al., 1991).

The analysis of complexity of inorganic crystal structures stored in the Inorganic Crystal Structure Database (Hellenbrandt, 2004) indicated that, among the 2000 most complex structures, about $90 \%$ belong to the compounds containing nanoscale-size atomic clusters with $82 \%$ represented by Mo-, W- and V-based POMs (Krivovichev, 2014). Therefore, it is not surprising that the first and the second most structurally complex minerals known so far, ewingite and morrisonite, respectively, are based upon nanoscale-size POM clusters of high nuclearity. It is noteworthy that the third most complex structure is ilmajokite that has a hierarchical multilevel titanosilicate framework structure, yet based upon complex trigonal prismatic titanosilicate clusters containing $\mathrm{Ce}^{3+}$ cations as central atoms (Zolotarev et al., 2020). Thus the formation of nanoscale clusters can be viewed as the leading mechanism of generating structural complexity in both minerals and synthetic inorganic crystalline compounds. The necessity to accommodate large clusters (most probably, preexisting in the crystallization media from which the crystals grow) results in the formation of large unit cells with high numbers of atoms that leads to the increasing amount of Shannon information).

Finally, we would like to point out that the majority of the minerals with POM clusters (34 out of 42) have been discovered and investigated in the 21st century (the outstanding contribution to the field by Anthony Kampf and coworkers should especially be mentioned), evidently due to the progress in the experimental and computational crystallography. Thus the discovery of POM minerals can be viewed as one of the specific landmarks of descriptive mineralogy and mineralogical crystallography of our time.

\section{Acknowledgements}

I am grateful to Aleksandar Kondinski and two anonymous reviewers for the useful comments on the manuscript.

\section{Funding information}

The following funding is acknowledged: Russian Science Foundation (grant No. 19-17-00038 to Sergey V. Krivovichev).

\section{References}

Andrade, M. B., Atencio, D., Menezes Filho, L. A. D. \& Spratt, J. (2018). Mineral. Mag. 82, 111-120.

Baker, L. C. W. \& Figgis, J. S. (1970). J. Am. Chem. Soc. 92, 3794-3797. Baur, W. H. \& Ohta, T. (1982). Acta Cryst. B38, 390-401.

Baur, W. H. \& Tillmanns, E. (1974). Acta Cryst. B30, 2218-2224.

Bennet, C. H. (1990). Complexity, Entropy, and the Physics of Information. Santa Fe Institute Studies in the Sciences of Complexity, edited by W. H. Zurek, Vol. VIII, pp. 137-148. Boston: Addison-Wesley.
Bi, L.-H., Kortz, U., Dickman, M. H., Nellutla, S., Dalal, N. S., Keita, B., Nadjo, L., Prinz, M. \& Neumann, M. (2006). J. Cluster Sci. 17, 143-165.

Blatov, V. A., Shevchenko, A. P. \& Proserpio, D. M. (2014). Cryst. Growth Des. 14, 3576-3586.

Britvin, S. N., Pekov, I. V., Yapaskurt, V. O., Koshlyakova, N. N., Göttlicher, J., Krivovichev, S. V., Turchkova, A. G. \& Sidorov, E. G. (2020). Sci. Rep. 10, 6345.

Brugger, J., Meisser, N., Krivovichev, S. V., Armbruster, T. \& Favreau, G. (2007). Am. Mineral. 92, 1630-1639.

Chubarova, E. V., Dickman, M. H., Keita, B., Nadjo, L., Miserque, F., Mifsud, M., Arends, I. W. \& Kortz, U. (2008). Angew. Chem. Int. Ed. 47, 9542-9546.

Colombo, F., Baggio, R. \& Kampf, A. R. (2011). Can. Mineral. 49, 849-864.

Cooper, M. A. \& Hawthorne, F. C. (2000). Can. Mineral. 38, 801808.

Cooper, M. A., Hawthorne, F. C., Kampf, A. R. \& Hughes, J. M. (2019a). Can. Mineral. 57, 235-244.

Cooper, M. A., Hawthorne, F. C., Kampf, A. R. \& Hughes, J. M. (2019b). Can. Mineral. 57, 245-253.

Cruciani, G., Orlandi, P., Pasero, M. \& Russo, M. (2005). Mineral. Mag. 69, 1037-1045.

Effenberger, H., Giester, G., Krause, W. \& Bernhardt, H. J. (1998). Am. Mineral. 83, 607-617.

Elliott, P., Giester, G., Rowe, R. \& Pring, A. (2014). Mineral. Mag. 78, 131-144.

Ercit, T. S. \& Hawthorne, F. C. (1995). Can. Mineral. 33, $1223-$ 1229.

Etxebarria, N., Fernández, L. A. \& Madariaga, J. M. (1994). J. Chem. Soc. Dalton Trans. pp. 3055-3059.

Evans, H. T. Jr \& Konnert, J. A. (1978). Am. Mineral. 63, 863-868.

Filatov, S. K., Semenova, T. F. \& Vergasova, L. P. (1992). Dokl. Akad. Nauk SSSR, 322, 539-539.

Filatov, S. K., Vergasova, L. P. \& Kutuzova, R. S. (2012). Minerals as Advanced Materials II, edited by S. V. Krivovichev, pp. 389-400. Berlin, Heidelberg: Springer-Verlag.

Filatov, S. K., Vergasova, L. P., Stepanova, E. L., Kutuzova, R. S. \& Polyakova, I. G. (2004). Proc. Russ. Mineral. Soc. 133, 1-11 (in Russian).

Friis, H. \& Casey, W. H. (2018). Can. Mineral. 56, 905-912.

Friis, H., Larsen, A. O., Kampf, A. R., Evans, R. J., Selbekk, R. S., Sánchez, A. A. \& Kihle, J. (2014). Eur. J. Mineral. 26, 567576.

Friis, H., Weller, M. T. \& Kampf, A. R. (2017). Mineral. Mag. 81, 543554.

Genkina, E. A. \& Khomyakov, A. P. (1992). Sov. Phys. Crystallogr. 37, 844-845.

Giuseppetti, G., Mazzi, F. \& Tadini, C. (1992). Neues Jahrb. Mineral. Monatsh. 1992, 113-126.

Gordillo, E. E., Linares, E., Toubes, R. O. \& Winchell, H. (1966). Am. Mineral. 51, 1-13.

Gross, J. T. \& Yellen, J. (2006). Graph Theory and Its Applications. Boca Raton, FL: CRC Press.

Hawthorne, F. C. \& Groat, L. A. (1986). Mineral. Mag. 50, 157162.

Hazen, R. M., Grew, E. S., Downs, R. T., Golden, J. \& Hystad, G. (2015). Can. Mineral. 53, 295-324.

Hazen, R. M., Papineau, D., Bleeker, W., Downs, R. T., Ferry, J., McCoy, T., Sverjensky, D. A. \& Yang, H. (2008). Am. Mineral. 93, 1693-1720.

Hellenbrandt, M. (2004). Crystallogr. Rev. 10, 17-22.

Herting, D. L. \& Reynolds, J. G. (2016). Environ. Chem. Lett. 14, 401405.

Hillebrand, W. F., Merwin, H. E. \& Wright, F. E. (1914). Proc. Am. Philos. Soc. 53, 31-54.

Hughes, J. M., Schindler, M. \& Francis, C. A. (2005). Can. Mineral. 43, 1379-1386. 
Hughes, J. M., Wise, W. S., Gunter, M. E., Morton, J. P. \& Rakovan, J. (2008). Can. Mineral. 46, 1365-1372.

Huskić, I. \& Friščić, T. (2018). Acta Cryst. B74, 539-559.

Huskić, I. \& Friščić, T. (2019). Philos. Trans. R. Soc. A, 377, 20180221.

Huskić, I. \& Friščić, T. (2020). Cryst. Growth Des. 20, 525-532.

Huskić, I., Novendra, N., Lim, D.-W., Topić, F., Titi, H. M., Pekov, I. V., Krivovichev, S. V., Navrotsky, A., Kitagawa, H. \& Friščić, T. (2019). Chem. Sci. 10, 4923-4929.

Huskić, I., Pekov, I. V., Krivovichev, S. V. \& Friščić, T. (2016). Sci. $A d v .2, \mathrm{e} 1600621$.

Kaku, M. (2014). The Future of the Mind. The Scientific Quest to Understand, Enhance and Empower the Mind. New York: Doubleday.

Kampf, A. R., Adams, P. M., Nash, B. P., Marty, J. \& Hughes, J. M. (2020a). Can. Mineral. 58, 125-135.

Kampf, A. R., Cooper, M. A., Hughes, J. M., Nash, B. P., Hawthorne, F. C. \& Marty, J. (2020b). Am. Mineral. 105, 123-131.

Kampf, A. R., Hughes, J. M., Marty, J. \& Brown, F. H. (2013a). Can. Mineral. 51, 27-38.

Kampf, A. R., Hughes, J. M., Marty, J., Gunter, M. E. \& Nash, B. (2011b). Can. Mineral. 49, 595-604.

Kampf, A. R., Hughes, J. M., Marty, J. \& Nash, B. (2012a). Can. Mineral. 50, 45-53.

Kampf, A. R., Hughes, J. M., Marty, J. \& Nash, B. (2013b). Can. Mineral. 51, 297-312.

Kampf, A. R., Hughes, J. M., Marty, J. \& Nash, B. P. (2011a). Can. Mineral. 49, 1243-1251.

Kampf, A. R., Hughes, J. M., Marty, J., Nash, B. P., Chen, Y. S. \& Steele, I. M. (2014a). Can. Mineral. 52, 1007-1018.

Kampf, A. R., Hughes, J. M., Nash, B. \& Marty, J. (2014b). Can. Mineral. 52, 15-25.

Kampf, A. R., Hughes, J. M., Nash, B. P. \& Marty, J. (2016b). Can. Mineral. 54, 145-162.

Kampf, A. R., Hughes, J. M., Nash, B. P. \& Marty, J. (2017c). Am. Mineral. 102, 461-465.

Kampf, A. R., Hughes, J. M., Nash, B. P. \& Marty, J. (2019). Am. Mineral. 104, 1851-1856.

Kampf, A. R., Hughes, J. M., Nash, B. P., Marty, J., Cooper, M. A., Hawthorne, F. C., Karpenko, V. Y., Pautov, L. A. \& Agakhanov, A. A. (2016a). Can. Mineral. 54, 555-558.

Kampf, A. R., Hughes, J. M., Nash, B. P., Marty, J. \& Rose, T. P. (2020c). Can. Mineral. 58, 137-151.

Kampf, A. R., Hughes, J. M., Nash, B. P., Wright, S. E., Rossman, G. R. \& Marty, J. (2014c). Am. Mineral. 99, 1045-1051.

Kampf, A. R., Mills, S. J., Rumsey, M. S., Dini, M., Birch, W. D., Spratt, J., Pluth, J. J., Steele, I. M., Jenkins, R. A. \& Pinch, W. W. (2012b). Mineral. Mag. 76, 1175-1207.

Kampf, A. R., Nash, B. P., Adams, P. M., Marty, J. \& Hughes, J. M. (2018a). Can. Mineral. 56, 859-869.

Kampf, A. R., Nash, B. P., Hughes, J. M. \& Marty, J. (2017b). Can. Mineral. 55, 473-481.

Kampf, A. R., Nash, B. P., Marty, J., Hughes, J. M. \& Rose, T. P. (2017a). Can. Mineral. 55, 207-217.

Kampf, A. R., Rossman, G. R., Ma, C., Belmonte, D., Biagioni, C., Castellaro, F. \& Chiappino, L. (2018b). Eur. J. Mineral. 30, 827834.

Kampf, A. R. \& Steele, I. M. (2008). Can. Mineral. 46, 679-686.

Kapustin, Y. L., Bykova, A. V. \& Bukin, B. I. (1972). Int. Geol. Rev. 14, 984-989.

Keggin, J. F. (1934). Proc. R. Soc. A, 144, 75-100.

Kondinski, A. \& Monakhov, K. Y. (2017). Chem. Eur. J. 23, 78417852.

Kondinski, A. \& Parac-Vogt, T. N. (2018). Frontiers Chem. 6, 346.

Krivovichev, S. (2012). Acta Cryst. A68, 393-398.

Krivovichev, S. V. (2013). Mineral. Mag. 77, 275-326.

Krivovichev, S. V. (2014). Angew. Chem. Int. Ed. 53, 654-661.

Krivovichev, S. V. (2015). Elements, 11, 443.
Krivovichev, S. V. (2016). Acta Cryst. B72, 274-276.

Krivovichev, S. V. (2017). Crystallogr. Rev. 23, 2-71.

Krivovichev, S. V. (2018). Z. Kristallogr. 233, 155-161.

Krivovichev, S. V., Mentré, O., Siidra, O. I., Colmont, M. \& Filatov, S. K. (2013). Chem. Rev. 113, 6459-6535.

Krivovichev, S. V., Yakovenchuk, V. N., Armbruster, T., Döbelin, N., Pattison, P., Weber, H.-P. \& Depmeier, W. (2004). Am. Mineral. 89, 1561-1565.

Krivovichev, S. V., Yudintsev, S. V., Stefanovsky, S. V., Organova, N. I., Karimova, O. V. \& Urusov, V. S. (2010). Angew. Chem. Int. Ed. 49, 9982-9984.

Kutuzova, R. S., Vergasova, L. P. \& Filatov, S. K. (2004). Volcanol. Seismol. 133, 46-54.

Kutuzova, R. S., Vergasova, L. P. \& Filatov, S. K. (2006). Eurasian Soil Sci. 39, 298-306.

Laverov, N. P., Sobolev, I. A., Stefanovskii, S. V., Yudintsev, S. V., Omel'yanenko, B. I. \& Nikonov, B. S. (1998). Dokl. Earth Sci. 363, 1104-1106.

Lindqvist, I. (1953). Ark. Kemi, 5, 247-250.

Miras, H. N., Vilà-Nadal, L. \& Cronin, L. (2014). Chem. Soc. Rev. 43, 5679-5699.

Miras, H. N., Yan, J., Long, D. L. \& Cronin, L. (2012). Chem. Soc. Rev. 41, 7403-7430.

Monakhov, K. Yu., Bensch, W. \& Kögerler, P. (2015). Chem. Soc. Rev. 44, 8443-8483.

Morgan, P. E. D. \& Ryerson, F. J. (1982). J. Mater. Sci. Lett. 1, 351-352.

Müller, A., Döring, J., Khan, M. I. \& Wittneben, V. (1991). Angew. Chem. Int. Ed. Engl. 30, 210-212.

Nakamura, S., Yamawaki, T., Kusaka, K., Otsuka, T. \& Ozeki, T. (2006). J. Cluster Sci. 17, 245-256.

Neumann, A., Klinkenberg, M. \& Curtius, H. (2018). Materials, 11, 1121.

Nyman, M. (2018). Encyclopedia of Geochemistry, edited by W. M. White. Cham, Switzerland: Springer International Publishing.

Nyman, M. \& Burns, P. C. A. (2012). Chem. Soc. Rev. 41, 7354.

Olds, T. A., Plášil, J., Kampf, A. R., Simonetti, A., Sadergaski, L. R., Chen, Y. S. \& Burns, P. C. (2017). Geology, 45, 1007-1010.

Pakhomova, A. S., Krivovichev, S. V., Yudintsev, S. V. \& Stefanovsky, S. V. (2013). Z. Kristallogr. Cryst. Mater. 228, 151-156.

Pakhomova, A. S., Krivovichev, S. V., Yudintsev, S. V. \& Stefanovsky, S. V. (2016). Eur. J. Mineral. 28, 205-214.

Pankova, Y. A., Gorelova, L. A., Krivovichev, S. V. \& Pekov, I. V. (2018). Eur. J. Mineral. 30, 277-287.

Pasero, M. (2020). The New IMA List of Minerals. http://pubsites.uws.edu.au/ima-cnmnc/.

Pekov, I. V., Zubkova, N. V., Göttlicher, J., Yapaskurt, V. O., Chukanov, N. V., Lykova, I. S., Belakovskiy, D. I., Jensen, M. C., Leising, J. F., Nikischer, A. J. \& Pushcharovsky, D. Y. (2014). Eur. J. Mineral. 26, 577-587.

Peterson, R. C., Metcalf, M., Kampf, A. R., Contreira Filho, R. R., Reid, J. \& Joy, B. (2019). Can. Mineral. 57, 827-841.

Pope, M. T. \& Müller, A. (1991). Angew. Chem. Int. Ed. Engl. 30, 3448.

Pope, M. T. \& Müller, A. (1994). Editors. Polyoxometalates: From Platonic Solids to Anti-Retroviral Activity. Dordrecht: Kluwer Academic Publishers.

Pope, M. T. \& Müller, A. (2001). Editors. Polyoxometalate Chemistry From Topology via Self-Assembly to Applications. Dordrecht: Kluwer Academic Publishers.

Privalov, V. I., Lapkin, V. V., Tarasov, V. P. \& Buslaev, Y. A. (1991). Mendeleev Commun. 1, 59-61.

Qiu, J. \& Burns, P. C. (2013). Chem. Rev. 113, 1097-1120.

Rakovan, J., Schmidt, G. R., Gunter, M. E., Nash, B., Marty, J., Kampf, A. R. \& Wise, W. S. (2011). Can. Mineral. 49, 1253-1265.

Reynolds, J. G., Cooke, G. A., Herting, D. L. \& Warrant, R. W. (2013). Ind. Eng. Chem. Res. 52, 9741-9751.

Rozhdestvenskaya, I., Mugnaioli, E., Czank, M., Depmeier, W., Kolb, U. \& Merlino, S. (2011). Mineral. Mag. 75, 2833-2846. 
Rozhdestvenskaya, I., Mugnaioli, E., Czank, M., Depmeier, W., Kolb, U., Reinholdt, A. \& Weirich, T. (2010). Mineral. Mag. 74, 159-177.

Rozhdestvenskaya, I. V., Kogure, E., Abe, T. \& Drits, V. A. (2009). Mineral. Mag. 73, 883-890.

Rozhdestvenskaya, I. V., Mugnaioli, E., Schowalter, M., Schmidt, M. U., Czank, M., Depmeier, W. \& Rosenauer, A. (2017). IUCrJ, 4, 223-242.

Rustad, J. R. (2010). Adv. Inorg. Chem. 62, 391-436.

Seichter, W., Mögel, H., Brand, P. \& Salah, D. (1998). Eur. J. Inorg. Chem. 1998, 795-797.
Swallow, A. G., Ahmed, F. R. \& Barnes, W. H. (1966). Acta Cryst. 21, 397-405.

Thompson, M. E., Roach, C. H. \& Meyrowitz, R. (1958). Am. Mineral. 43, 749-755.

Vergasova, L. P., Stepanova, E. L., Serafimova, E. K. \& Filatov, S. K. (1997). Proc. Russ. Mineral. Soc. 126, 104-110 (in Russian).

Witzke, T. (1997). Neues Jahrb. Mineral. Monatsh. 1997, 301-308.

Yang, P. \& Kortz, U. (2018). Acc. Chem. Res. 51, 1599-1608.

Zolotarev, A. A., Krivovichev, S. V., Cámara, F., Bindi, L., Zhitova, E. S., Hawthorne, F. \& Sokolova, E. (2020). IUCrJ, 7, 121-128. 